\title{
Use-wear and residue analysis of knapped stone artefacts from Lepenski Vir and Padina (Serbia)
}

\author{
Anđa Petrović ${ }^{1,2}$, Cristina Lemorini ${ }^{1}$, Stella Nunziante-Cesaro ${ }^{3}$, \\ Dušan Mihailović ${ }^{2}$
}

1. Sapienza University of Rome, Laboratory of Technological and Functional Analyses of Prehistoric Artefacts. Piazzale Aldo Moro 5, 00136, Rome, Italy. Email: Petrović: anda.petrovic@uniroma1.it;

Lemorini: cristina.lemorini@uniroma1.it

2. University of Belgrade, Faculty of Philosophy, Department of Archaeology. Čika Ljubina 18-20, 11000, Belgrade, Serbia. Email: dmihailo@f.bg.ac.rs

3. SMATCH Italia (Scientific Methodologies Applied to Cultural Heritage). Largo Ugo Bartolomei 5, 00136, Rome, Italy. Email: snunziantecesaro@gmail.com

\begin{abstract}
:
Following a series of published analyses ranging from architecture to prehistoric diet of the Iron Gates' inhabitants, our research aims to present new results regarding use-wear analysis of knapped stone artefacts from Lepenski Vir and Padina with a particular focus on the transition from Mesolithic to Neolithic in this region. Use-wear and residue analysis are applied using the low and high-power approach by Optical Light Microscope (OLM) observations combined with FTIR analysis.

Based on the results, some of the main activities that took place in Iron Gates are processing of hide, bone, antler, plants, and soft stone. It is very important to highlight the complexity of various processes, which make this already specific area more peculiar. A variety of both simple, but overall, more complex and composite activities are recorded with the elaborate preparation of the used materials, for example, hide. Particular processes, such as butchering, were noted both inside the houses, and also concentrated in precise, specific areas of the settlements, where only tools involved in the processing of hide and meat were found. The data obtained highlight the activities of these advanced hunter-gatherer-fishermen and first farmers communities. Together with spatial analysis, the dynamics and processes in the Late Mesolithic and Early Neolithic are revealed, but also many questions regarding the specialization of the prehistoric settlements on the Danube are posed.
\end{abstract}

Keywords: knapped stone tools; use-wear analysis; FTIR analysis; Mesolithic; Neolithic; Lepenski Vir; Padina

\section{Introduction}

For decades, a closed eco-niche like the Iron Gates in eastern Serbia enabled specialists to explore the transition to a sedentary life, with an exceptional record of human occupation during the Late Glacial and Early Holocene. Having this in mind, results of use-wear and residue analysis of knapped stone tools from the Iron Gates are interpreted in the wider study

Journal of Lithic Studies (2021) vol. 8, nr. 2, 29 p.

DOI: https://doi.org/10.2218/jls.6695

Published by the School of History, Classics and Archaeology, University of Edinburgh ISSN: 2055-0472. URL: http://journals.ed.ac.uk/lithicstudies/

Except where otherwise noted, this work is licensed under a CC BY 4.0 licence. 
focusing on daily routine, but also addressing some long-term aspects like changes in the economy.

In this paper, use-wear analysis of knapped stone tools from particular contexts will be discussed with an accent on a variety of used materials and activities during diverse phases. The idea is to present some of the important contexts from the sites of Lepenski Vir and Padina and to discuss the processes that took place in the Iron Gates area and how they define the specific period.

Lepenski Vir and Padina are located on the right terrace of the Danube river in the Upper Gorges (Figure 1). The sites were excavated during the 1960s and 1970s (Jovanović 1987; Srejovic 1969), and after the excavations, the sites were submerged with water, for the purposes of constructing the hydropower plant Đerdap I.

Recovered archaeological material from the region left numerous possibilities for researchers nowadays together with unanswered questions and hypothesis. Absolute dating of the sites is available and published in various articles and books (Bonsall et al. 2004; 2008; Borić 2016; 2019; Borić et al. 2004; 2018; Borić \& Dimitrijević 2007; Borić \& Miracle 2004). Besides the revision of stratigraphy and chronology, many other studies were done, like human remains analysis (Borić 2016; Borić \& Stefanović 2004; Cristiani et al. 2016; Radović \& Stefanović 2015; Roksandić 2000; 2012), techno-typological analysis of ground stone (Antonović 2006; Radovanović 1992; 1996) and knapped stone artefacts (Kozłowski \& Kozłowski 1984; Mihailović 2004; Mitrović 2018; Radovanović 1996; Šarić 2014), archaeobotanical analysis (Filipović et al. 2010), analysis of faunal remains (Bökönyi 1972; Dimitrijević 2000; 2008, Dimitrijević et al. 2016; Živaljević et al. 2017), followed by isotope analysis (Jovanović et al. 2020).

The period of inhabitation of the excavated open-air settlements in the Iron Gates is long, from the Early Holocene, around $9600 \mathrm{cal}$ BCE to the Late Eneolithic-Early Iron Age (Borić 2011; Radovanovic 1996). The specific chronological frame that would be the focus of this paper is the transitional period from Mesolithic to Neolithic around the end of the $7^{\text {th }}$ to the mid- $6^{\text {th }}$ millennium BCE.

\subsection{The knapped stone industry of Lepenski Vir}

The analysis of the knapped stone industry from the Lepenski Vir site was published by Polish authors J. K. Kozłowski and S. K. Kozłowski (1984), and it was later summarized by I. Radovanovic (1996). The classification of stone raw materials originates from the first authors of the analysis and it was done with the help of petrologist M. Pawlikowski (Kozłowski \& Kozłowski 1984: 253-293).

The Preneolithic layer I, or, according to D. Srejović, Lepenski Vir I, includes artefacts made from 18 different raw materials. Most of the tools are made of grey radiolarite and greyish flint and quartz (Kozłowski \& Kozłowski 1984: table 1). The first two appear in limestone from the geological era of the Mesozoic, and the third can be found in alluvial deposits of the Danube. The smaller group consists of raw materials brought from different regions as grey non-transparent flint, grey transparent, Balkan flint and black flint. Grey radiolarite was used mainly to produce cores, splintered pieces and flakes while greyish flint was used for flakes and blades.

The general structure of this layer, which is connected to the horizon of the trapezoidal houses, mostly consists of flakes and debitage (70.72\%), unretouched blades (13.8\%), cores and splintered pieces (8.54\%) and retouched tools (6.9\%), (Radovanović 1996). 


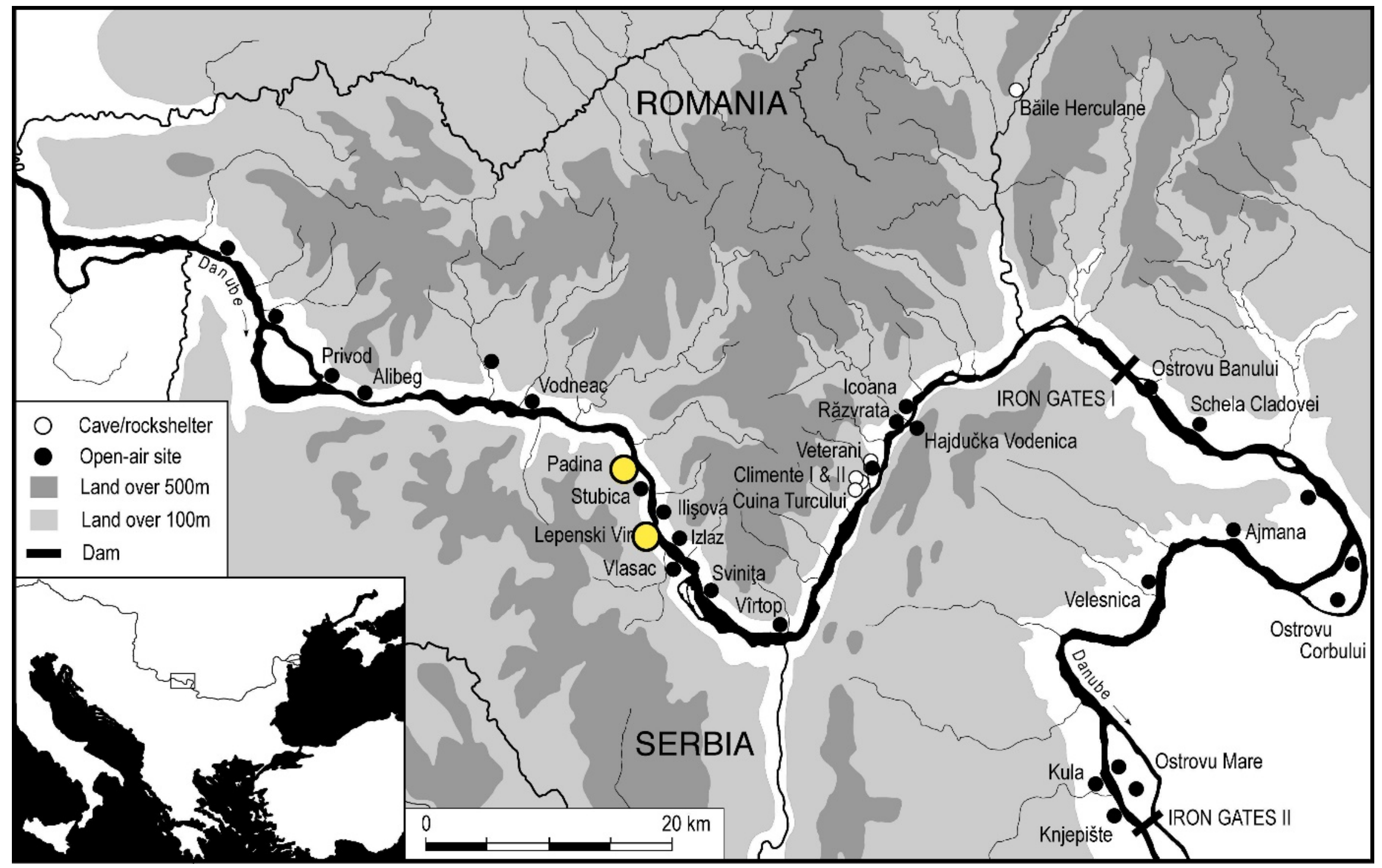

Figure 1. Map of Iron Gates region, map courtesy of C. Bonsall (after Bonsall et al. 2008). 
In pottery Neolithic layers IIIa, b the most used raw material is Balkan flint with $65.73 \%$ of use in the total structure. The exact source of this raw material has not been determined at the time of processing the technological characteristics, and the situation has not been resolved satisfactorily to date (Bogosavljević-Petrović \& Starović 2013; Gurova 2008; Kozłowski \& Kozłowski 1984: 267). In a more recent study, where laser ablation analyses were mainly performed on samples of Balkan flint, a strong signal of origin points to the area around Nikopol and Pleven in Bulgaria (Gurova et al. 2016: 438-440). Quartzite is on the second place of extraction, flint with stripes is in the third place, while grey radiolarite and grey flint are less frequent (Kozłowski \& Kozłowski 1984: 271). The typological structure of the industry in this layer mainly consists of flakes and debitage (68.71\%), unretouched blades (19.55\%), retouched tools (8.65\%), and cores and splintered pieces (3.07\%). For this phase of the Lepenski Vir settlement, we can say that the population exploited less the local sources and that they used mainly imported raw materials from eastern regions (Kozłowski \& Kozłowski 1984) emphasizing the production of cores, blades and tools on Balkan flint in the Early Neolithic horizon (Bogosavljević-Petrović \& Starović 2013: 87).

\subsection{The knapped stone industry of Padina}

The knapped stone industry of Padina was studied carefully together with a focus on procurement and exploitation of the raw materials (Mihailović 2004; Radovanović 1981; 1992; 1996). The site is characterized by two archaeological horizons, Padina A, the second half of the ninth millennium cal BCE, and Padina B that belongs to the transition from Mesolithic to Neolithic (Jovanović 1987). Even though, the majority of the tools observed in this paper originate from Padina B we still think that it is important to summarize some of the main technological and typological characteristics of Padina A as well, for the purpose of wider discussion. The technology of the industry from Padina A is based on three traditions: lamellar, flake technology and bipolar technology (Mihailović 2004; Radovanović 1996) together with a large variability of the raw materials used for knapping with a predominance of flakes over blades. The high presence of cores and tools such as end-scraper, retouched flakes, side scrapers and backed pieces is noted (Mihailović 2004; Radovanović 1981; 1996).

Padina B horizon characteristics are noted in Sector III. The general structure shows a very low percentage of cores and a high percentage of tools together with a small number of blades (Mihailović 2004: table 1). This implies that the workshop was situated outside the centre of the settlement. Retouched tools are represented by retouched and notched blades, most distinctive of which are perforators and awls on blades (Mihailović 2004:64).

Tools were manufactured on Balkan flint, beige-brown flint, grey flint and chalcedony, while chert, siliceous rocks and quartz were not used for tool production. It should be stated that raw material classification was not done by a geologist and that, so far, specialist petrological analysis of the Padina assemblage is not available.

Two traditions of technology are present at Padina B, an older tradition with quartz tools, bipolar technology and a high percentage of flakes and flake tools, and a younger tradition characterized by blade technology (Mihailović 2004:67).

\section{Materials and methods}

\subsection{Archaeological context}

The selection of knapped stone tools was done based on the context, with an idea to study the activities from diverse areas as house floors, under the house floors, ash places, open-air areas, and middens. These different settlement areas are important for testing the 
heterogeneity of the activities that took part, and they can imply the perception of the use of these zones within the communities.

The analysed lithic tools from Lepenski Vir came from under the floor of house 26, house 36, house 32 and one midden (square C/X, XI, III excavation layer), (Figure 2). The dated sample from under the floor of house 26 relates to the use of trapezoidal buildings 6212-6025 cal BCE (Borić \& Dimitrijević 2007: 20), and the sample from the hearth of house 36 is dated to between 6198-5928 cal BCE (Borić \& Dimitrijević 2007: 18). House 32 is stratigraphically connected to two other houses $(20,33)$ and is the youngest house in the sequence, dated to the 6061-5902 cal BCE (Borić \& Dimitrijević 2007: 24). The material found in the midden is connected to the Neolithic period, comprising two flake fragments, a cortical and blade-like flake, made on Balkan flint. This observation is supported by the fact that other artefacts found in this layer and block are typologically and technologically determined as tools connected to the Early Neolithic (Starčevo) phase of Lepenski Vir.

The material analysed from Padina came from Sector I and Sector III (trench 3, 5 and 6). Tools found in Sector I (Figure 3), block 1b are dated 6650-6460 cal BCE, the transitional period of the Iron Gates (Borić \& Miracle 2004: 348), while two artefacts come from profile 3, segment 2 were found with Starčevo pottery placing them in Early Neolithic period.

Regarding Sector III (Figure 4), in trench 5, block 1 three houses were recovered (house $16,17,18)$, one date indicated occupation or abandonment of house 17 in the range 6250$6025 \mathrm{cal} \mathrm{BCE}$. One antler from the floor of the house 18 is dated to 5990-5720 cal BCE and a dog ulna found underneath to 6440-6210 cal BCE both vertically stratified within the same building (Borić \& Miracle 2004: 351-352). In block 2, two dates were extracted from the material beneath house 15, one from the burial 9360-8920 cal BCE, and another one by dating a worked bone which corresponds to the occupation of the house - 5780-5560 cal BCE (Borić \& Miracle 2004: 352-353). The dates from house 15 and 18 (5990-5720 cal BCE and 57805560 cal BCE) indicated the later phase of the Early Neolithic occupation of the site. It is important to highlight that these samples derive from bones found in the association with Early Neolithic pottery and they represent the earliest phase of the Early Neolithic period in this region (Borić \& Miracle 2004: 352). Trench 6 has three dated burials (b. 15 - 8450-7960 cal BCE, b. 14 - 8690-8230 cal BC, b. 12 - 8750-83330 cal BC) that belong to the Early Mesolithic period, implying that maybe in this period this area was used for funerary practices (Borić \& Miracle 2004: 345, 352-353). There are no absolute dates dating trench 3, so the results of the use-wear analysis of knapped artefacts coming from this area will be discussed in regard to the stone construction found in the block 1 . 


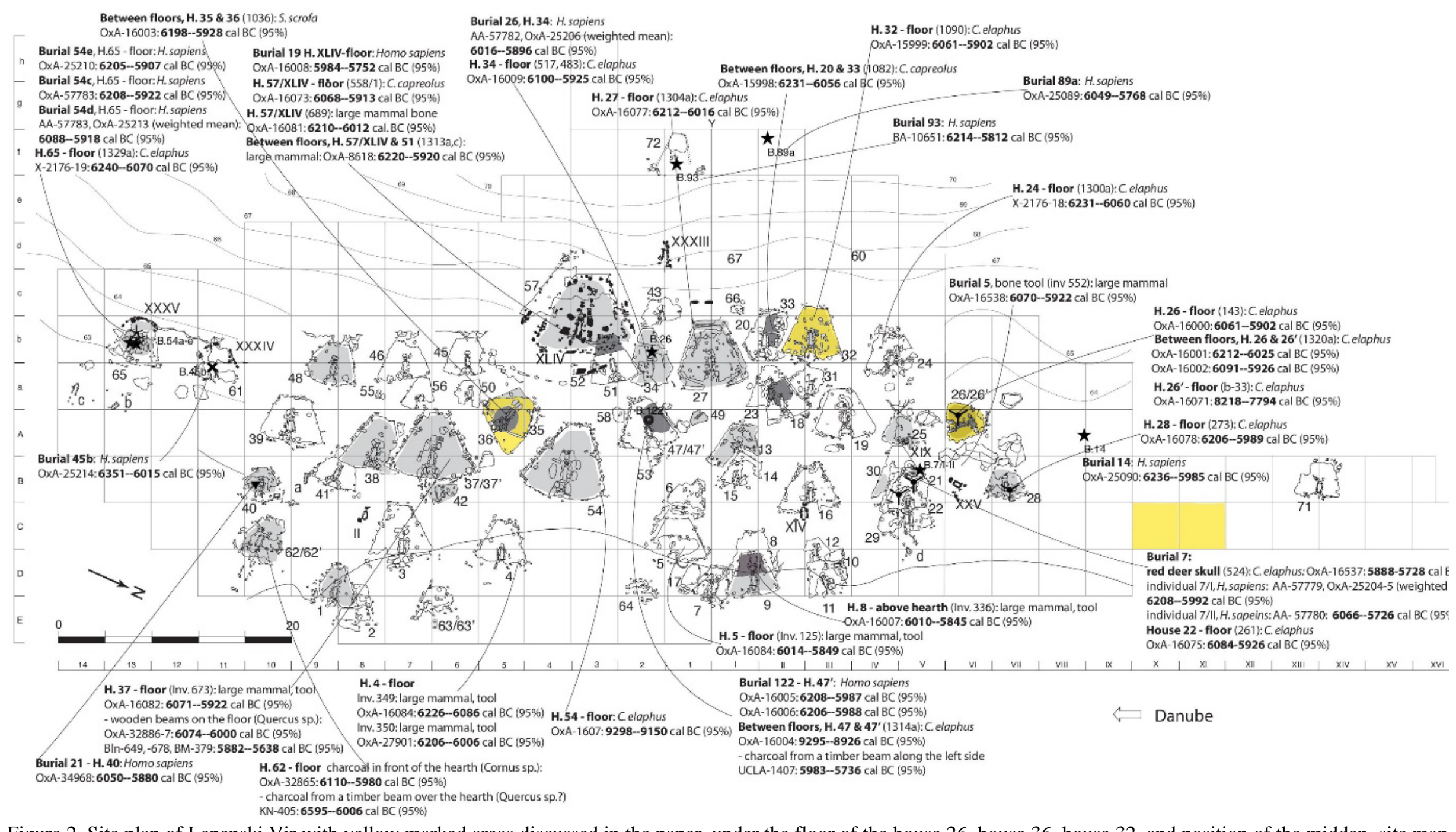

Figure 2. Site plan of Lepenski Vir with yellow marked areas discussed in the paper, under the floor of the house 26, house 36, house 32, and position of the midden, site map courtesy of D. Borić (after Borić et al. 2018: SI fig. 2). 


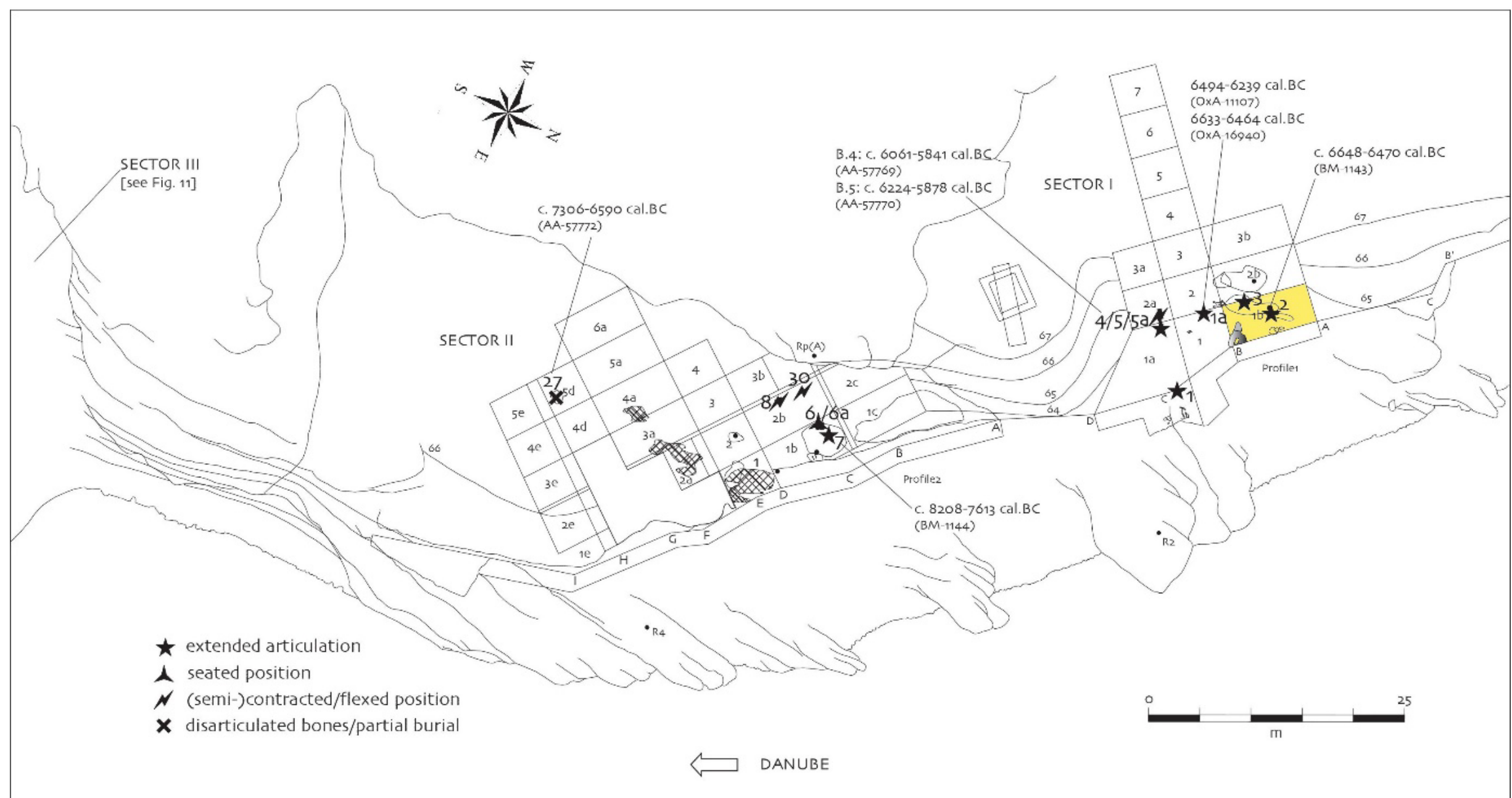

Figure 3. Site plan of Sector I and II, Padina site with the yellow marked area is where the tools are collected from Sector I, site map courtesy of D. Borić (after Borić 2011: fig. 11). 


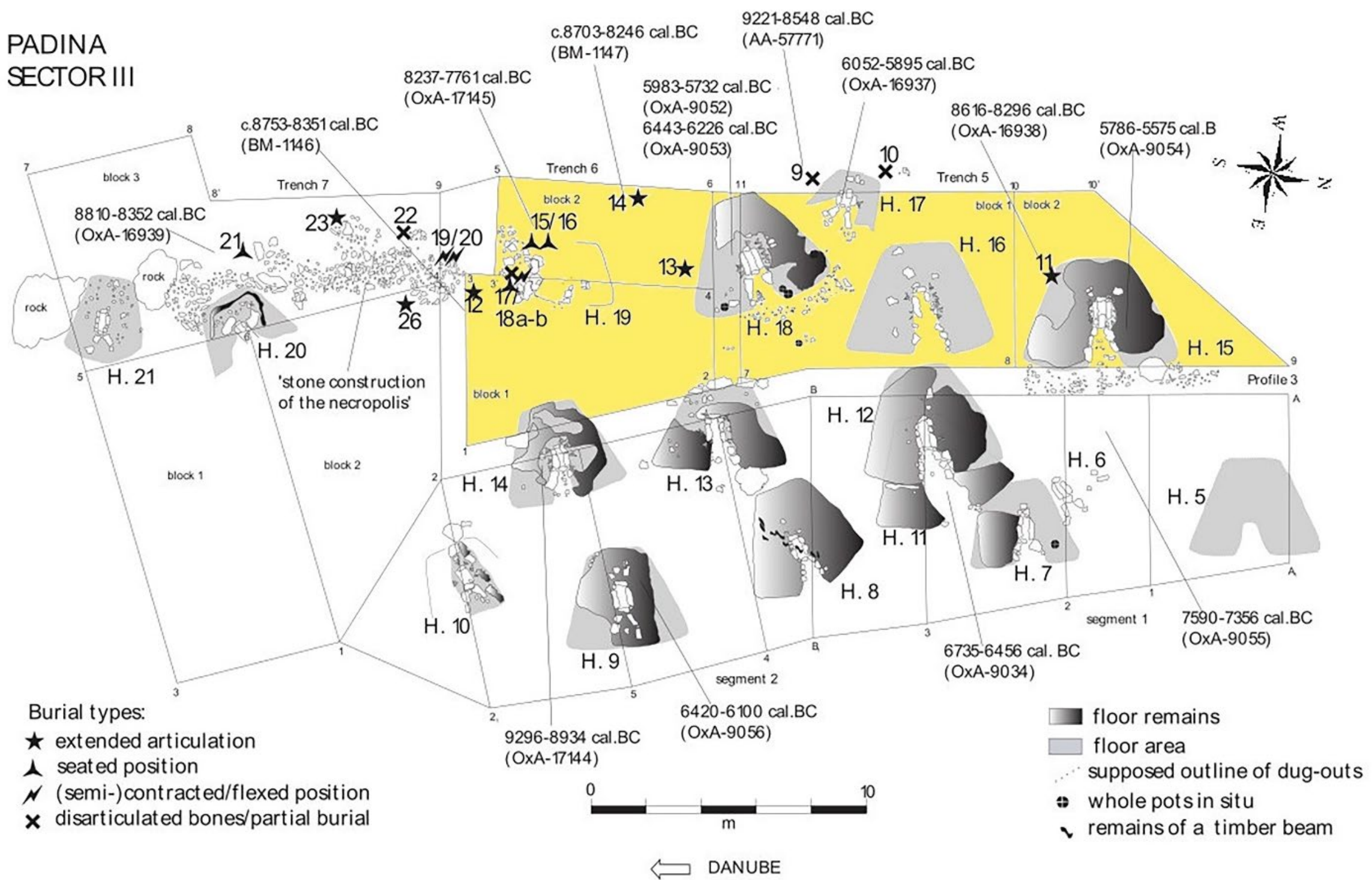

Figure 4. Site plan of Sector III with yellow marked areas that are discussed in the paper, site map courtesy of D. Borić (after Borić 2011: fig 12). 


\subsection{Archaeological sample}

In total, for this paper, one hundred and twenty (120) artefacts were observed: one hundred and nineteen (119) flint tools and one (1) obsidian blade (Supplementary file 1). Of these, seventy-six (76) tools are from Lepenski Vir (Figure 5), and forty-four (44) from Padina (Figure 6). In addition to use-wear analysis, 25 tools were analysed with FTIR spectroscopy, of which fourteen (14) are from Lepenski Vir and eleven (11) artefacts from Padina site.

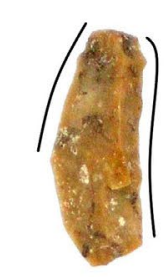

1
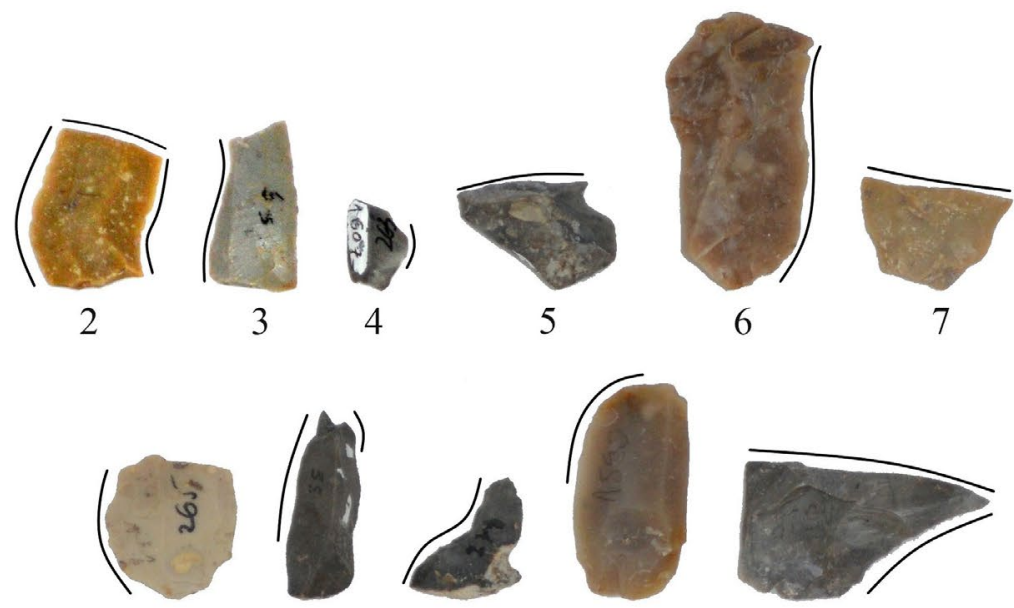

8

10

11

12

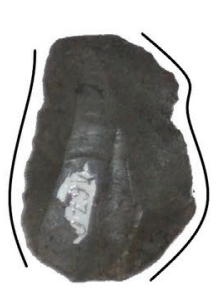

13

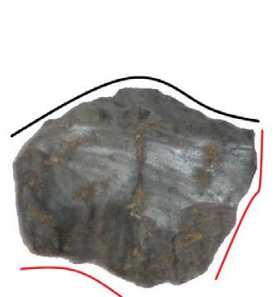

14

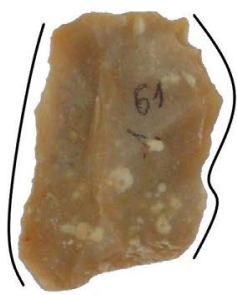

15

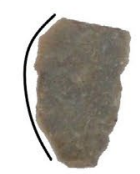

16

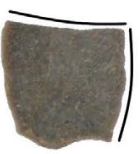

17

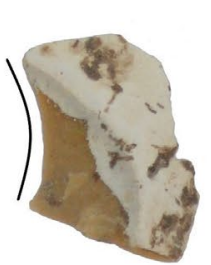

18

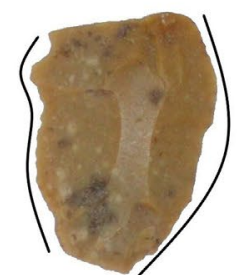

19

0 $5 \mathrm{~cm}$

Figure 5. Knapped stone tools from Lepenski Vir, part of the analysed sample discussed and represented in the paper, black line - area of use, red line - prehension area (1 - under the floor of house 26 (sample 63), 2-12 house 36 (samples 3, 29, 24, 15, 4, 20, 11, 2, 25, 7, 14), 13-17 - house 32 (samples 56, 31, 35, 39, 41), 18-19 midden (samples 75, 76)). 


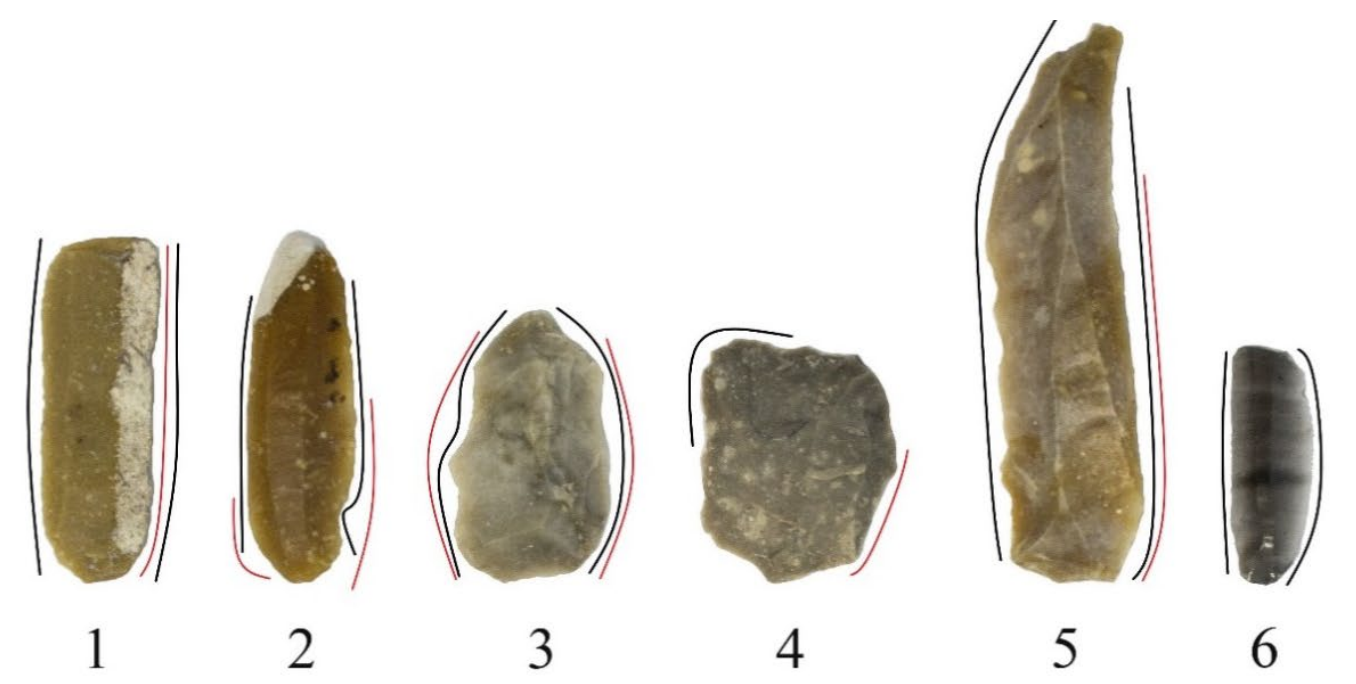

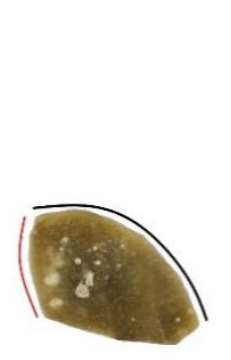

7

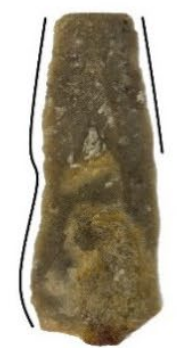

8

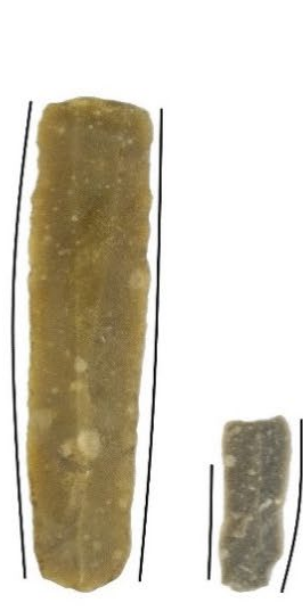

$9 \quad 10$

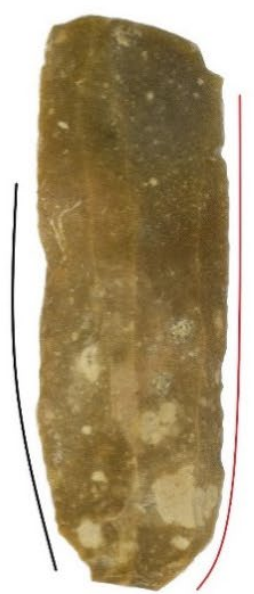

11

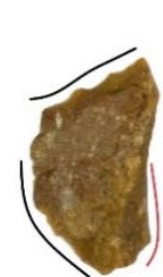

12

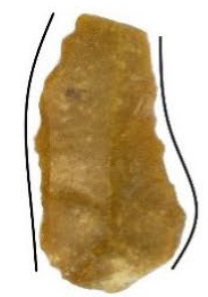

13

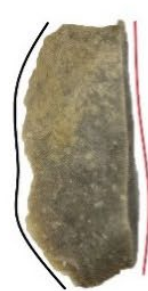

14

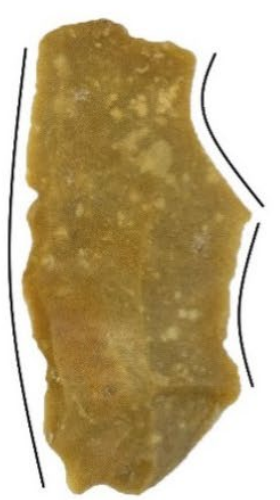

15

0

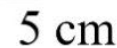

Figure 6. Knapped stone tools from Padina site, part of the analysed sample discussed and represented in the paper, black line - area of use, red line - prehension area (1-6 - Sector I (sample 77-82), 7-10 - Sector III, trench 5 (sample 97, 100, 101, 102), 11 - Sector III, trench 6 (sample 120), 12-15 - Sector III, trench 3 (sample 113, $115,114,117))$. 


\subsection{Methodology and equipment used in the study}

The archaeological material was analysed by low- and high-power approach in Laboratory of Technological and Functional Analysis of Prehistoric Artefacts (LTFAPA) at the Sapienza University of Rome, using Stereomicroscope Nikon SMZ-U with reflected light (x0.5 objective, x10 oculars, range of magnifications from $0.75 \mathrm{x}$ to $7.5 \mathrm{x}$ ), Metallographic microscope Nikon Eclipse ME 600 (x5, x10, x20, x50, x100 oculars), and digital microscope Hirox RH 2000. The photos were processed with Helicon Focus software, which is used for merging a large number of photos with different focus distances into one, single image with greater depth of field. A glossary with specific use-wear terms used in the study is included in the Supplementary file 2.

The Fourier Transform InfraRed (FTIR) spectra of the knapped stone tools were collected with a Bruker Optic Alpha-R portable interferometer with an external reflectance head covering a circular area of about $5 \mathrm{~mm}$ in diameter. The analysis is not destructive nor invasive since it does not require preliminary treatment of the samples. A few points of each artefact were examined in the same experimental conditions in order to compare the spectra obtained. The investigated spectral range was 7500-375 cm $\mathrm{cm}^{-1}$ with a resolution of $4 \mathrm{~cm}^{-1}$ cumulating 250 scans or more. Figures reported in the following, however, show only the spectral range where infrared active absorption bands were observed.

For the cleaning of the knapped artefacts, we used a standard cleaning procedure of the LTFAPA Laboratory. The protocol consists of 15 minutes of cleaning in an ultrasonic tank with a mixture of demineralized water and Derquim ${ }^{\circledR}$ soap. Afterwards, they were cleaned once again with demineralized water for 10 minutes. The tools that were less dirty and barely altered were only washed with demineralized water in an ultrasonic tank for 15 minutes.

\section{Results}

\subsection{Results of the use-wear analysis}

In total, only six (6) tools out of one-hundred and twenty (120) were not used. All together both altered and non-diagnostic tools are 22 (18\% of the sample), out of which 9 tools have traces associated with a cutting motion, as the only information possible to extract.

\subsubsection{Alterations}

Before presenting the results of use-wear and residue analysis some specific conclusions regarding the post-depositional modifications should be noted. Tools from Lepenski Vir, both based on the total number of the analysed artefacts, including the ones discussed in this paper are among the most altered tools coming from the Iron Gates region. The artefacts are well preserved, but they are altered both mechanically and chemically. Among the most pronounced alterations we can single out thermal stress (Figure 5: 13 and Figure 7: a) and chemical alterations that altered the physical characteristics of the surface (Figure 6: 6 and Figure 7: b), roots and root negatives (Figure 5: 2, Figure 7: c, Figure 5: 14 and Figure 7:d), glossy appearance, white patina (Figure 5: 15 and Figure 7: e) and mechanical abrasions that smoothed the surface creating a gloss visible even with the naked eye (Figure 5: 15 and Figure 7: f). Thermal stress damaged the surface and covered some of the micro-traces leaving the specific worked material not possible to decipher. The specific connection between the thermal stress and micro polish has been tested, and direct proof that fire altered the traces and the polish is not yet proven, at least, not in the heating of used tools up to 808 ${ }^{\circ} \mathrm{C}$ (Petrović \& Moscone 2019). Even though the heat treatment studies with the implementation of various analytical techniques is a well-researched field (e.g., Domanski \& Webb 1992; Gurova et al. 2020; Patterson 1995; Purdy 1971; Schmidt et al. 2012), the impact 
of heating after or during use, together with microwear preservation on the flint tools is yet to be tested (Binder \& Gassin 1988; Clemente Conte 1997; Halbrucker et al. 2021; Olausson 1983; Rutkoski et al. 2019).
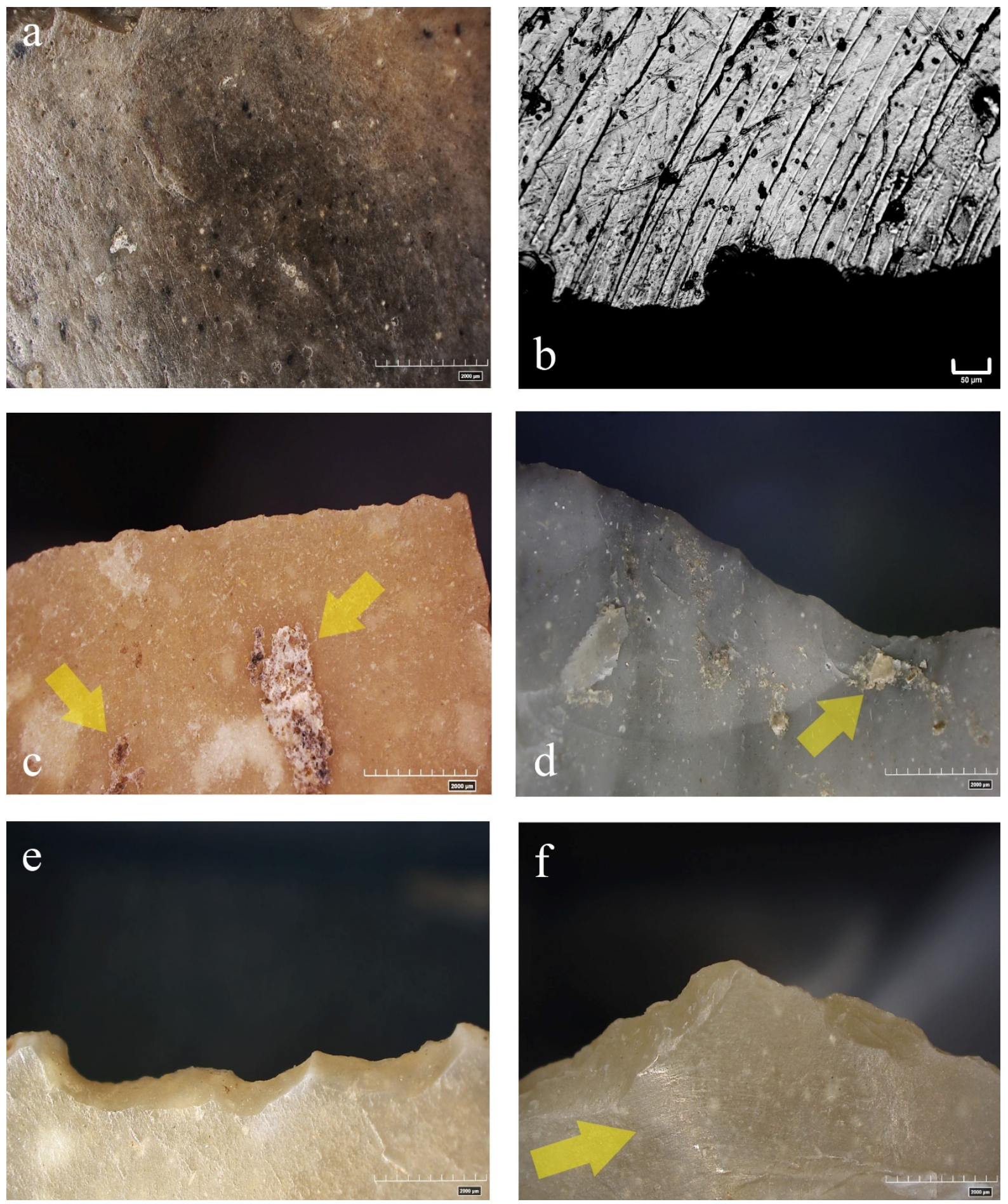

Figure 7. Post-depositional surface modifications a) thermal stress, sample 56, Lepenski Vir, digital microscope, scale bar equal to $2000 \mu \mathrm{m}$, b) pits from chemical alteration on the obsidian blade, sample 82, Padina, metallographic microscope, scale bar equal to $50 \mu \mathrm{m}$, c) root negatives (indicated by arrows) on the tool's surface, sample 3, Lepenski Vir, digital microscope, scale bar equal to $2000 \mu \mathrm{m}$, d) root negatives on the working edge, sample 31, Lepenski Vir, digital microscope, scale bar equal to $2000 \mu \mathrm{m}$, e) white patina, sample 35, Lepenski Vir, digital microscope, scale bar equal to $2000 \mu \mathrm{m}, \mathrm{f}$ ) mechanical abrasion (indicated by arrow), sample 35, Lepenski Vir, digital microscope, scale bar equal to $2000 \mu \mathrm{m}$. 
On the other hand, tools from Padina are less altered, but the glossy appearance is still present on some of the pieces and thermal stress is very rare.

\subsubsection{Animal resources}

Working on animal materials was one of the most prominent activities in the Iron Gates region present both at the Lepenski Vir and Padina. Edge rounding is usually very pronounced on the tools used for hard animal materials like bone and antler (Figure 8: a, Figure 8: c and e), with snap, step and sometimes feather and half-moon scar shapes. Based on the macro traces it is not possible to distinguish between traces made by antler or bone, but sometimes it is possible to do so, based on the polish. In the case of sample 113 (Figure 5: 12), and sample 115 (Figure 5: 13) melted topography was noted, which is one of the main characteristics of a micro polish that is a result of antler working (Figure 8: $\mathrm{d}$ and $\mathrm{f}$ ).

The material that was frequently worked is animal skin or hide. Hide was worked in all conditions - dry, semi-dry, semi-fresh, fresh, hide with additives. The importance of the Lepenski Vir sample, also noticeable on the tools from Padina, is that all these phases of work are visible based on micro traces and residues.

Macro scars are defined with step, snap and hinged and in rare cases some feather and halfmoon terminations. Regarding the motion and activity both cutting and scraping is present.

Granular topography (Figure 9: a-e, g and h) that has a half-tight to tight linkage and rough texture is a generic description of the polish traces and can come in many variations, like being brighter or having a looser or tighter connection. The granular topography, in many cases, is combined with domed type on the high parts. Dry hide polish is noted on sample 81 (Figure 6: 5), concentrated on the outer edge with a tight linkage and a mixture of flat and domed topography (Figure 9: a), while fresh hide has a looser linkage, and the topography is granular with a rough texture (Figure 9: c). Flake (sample 24, Figure 5: 4) was used for working on the details of the hide where the polish has a very specific extension on edge and surface (Figure 9: d).

Butchering is also present both at the Lepenski Vir and Padina and is usually connected to the smaller scars and soft material. The differences in the traces can be variable depending on the materials that came into contact with a lithic tool (Figure 9: e-h). During butchering activity, various materials come into contact with the lithic tools, such as meat (or other soft tissues as muscles, tendons or ligaments), hide and bone. These variations are visible in archaeological sample 75 (Figure 5: 18), where the tool came into contact only with meat, creating a smooth texture and small micro scars (Figure 9: e) and sample 79 (Figure 6: 3), where flat, domed and granular topography indicated butchering activity and contact with meat, hide and bone (Figure 9: f). This flake is distinctive since the traces are covered with prehension patches, characterised by flat topography and smooth texture on both edges, caused by the gripping of the tools between the fingers. The localization of these patches of polishing indicates the use of both edges extensively, rotating them when needed. 

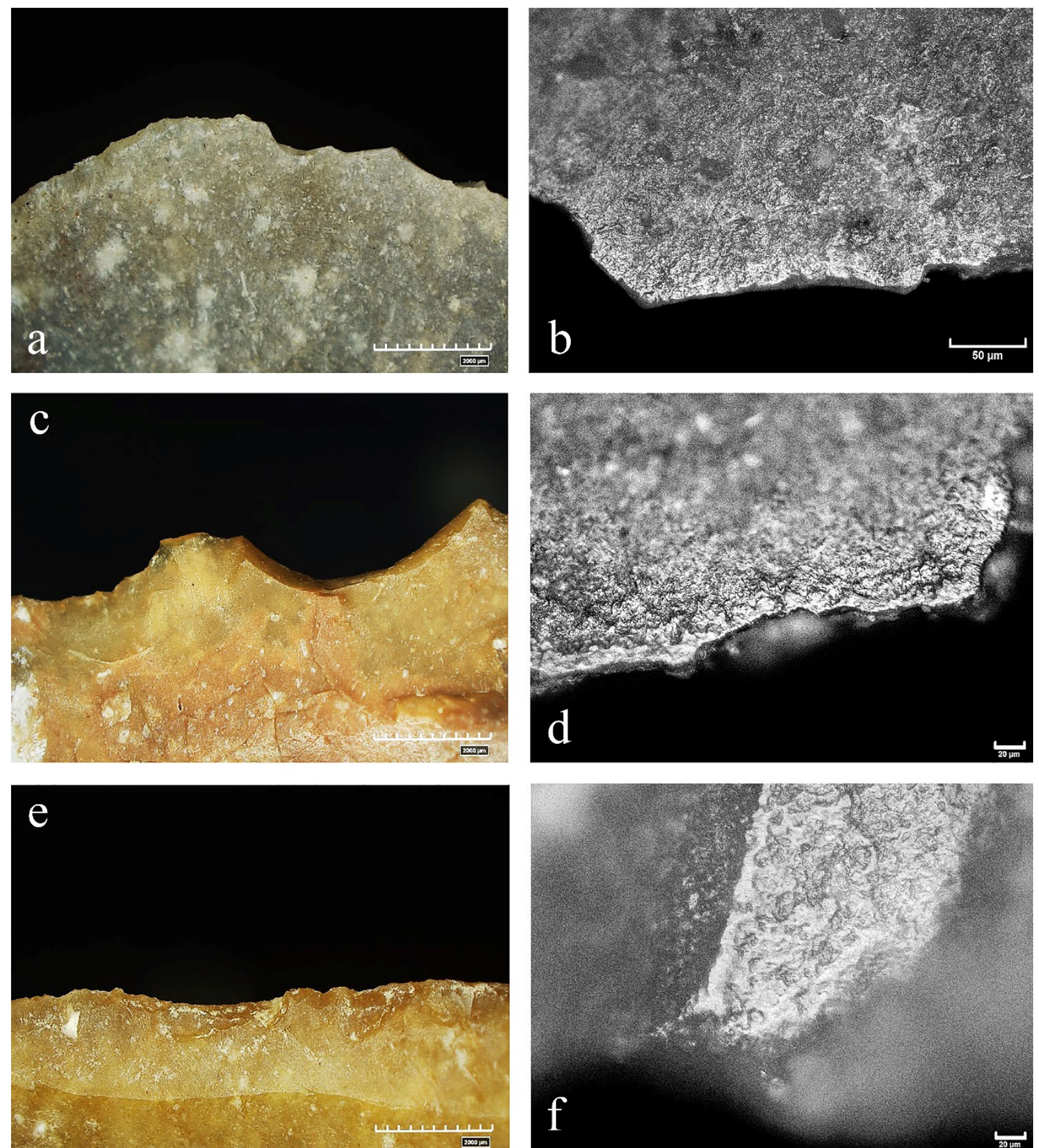

Figure 8. Hard animal materials a) macro traces of bone working, sample 114, Padina, digital microscope, scale bar equal to $2000 \mu \mathrm{m}$, b) micro traces of bone working, sample 114, metallographic microscope, scale bar equal to $50 \mu \mathrm{m}$, c) macro traces of antler working, sample 113, Padina, digital microscope, scale bar equal to $2000 \mu \mathrm{m}$, d) micro traces of antler working, sample 113, metallographic microscope, scale bar equal to $20 \mu \mathrm{m}$, e) Edge rounding, use on antler, sample 115, Padina, digital microscope, scale bar equal to $2000 \mu \mathrm{m}, \mathrm{f}$ ) detail of polish, antler, sample 115, metallographic microscope, scale bar equal to $20 \mu \mathrm{m}$. 

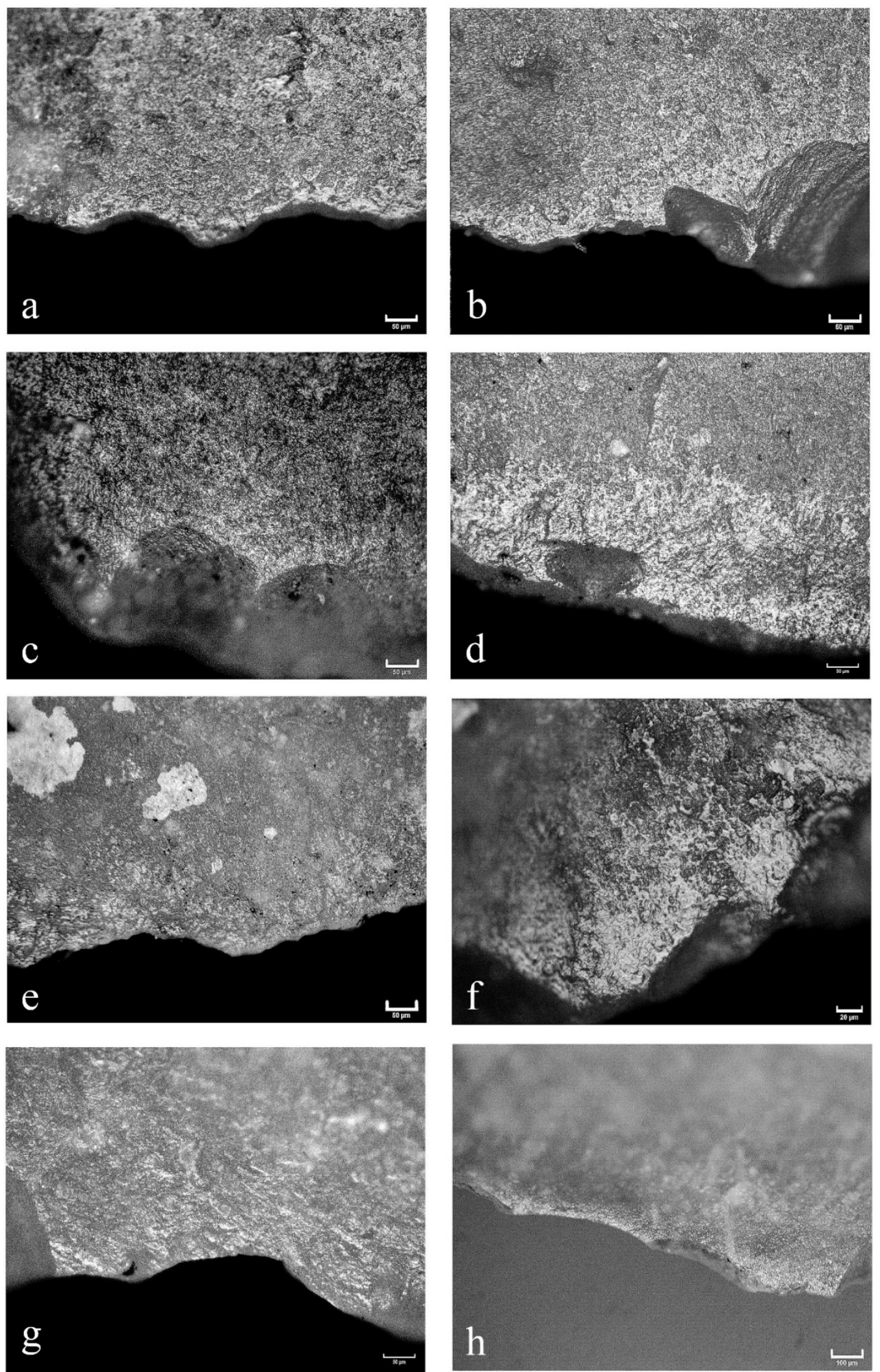

Figure 9. Medium and soft animal material, different phases of hide working, soft tissues, meat and traces of butchering, metallographic microscope a) dry hide, sample 81, Padina, scale bar equal to $50 \mu \mathrm{m}$, b) not the dries hide, towards fresh, sample 29, Lepenski Vir, scale bar equal to $50 \mu \mathrm{m}$, c) fresh hide, sample 24, Lepenski Vir, scale bar equal to $50 \mu \mathrm{m}$, d) working details on hide, sample 15, Lepenski Vir, scale bar equal to $50 \mu \mathrm{m}$, e) butchering, sample 75, Lepenski Vir, scale bar equal to $50 \mu \mathrm{m}, \mathrm{f}$ ) butchering, sample 79, Padina, scale bar equal to $20 \mu \mathrm{m}, \mathrm{g}$ ) butchering and skinning, sample 77, Padina, scale bar equal to $50 \mu \mathrm{m}, \mathrm{h}$ ) meat working, sample 97 , Padina, scale bar equal to $100 \mu \mathrm{m}$. 


\subsubsection{Vegetal resources}

The analysed samples from Lepenski Vir and Padina showed the presence of vegetal materials like herbaceous and siliceous plants, tubers, wood-like plants and wood. Based on this sample, these materials were less frequently worked with almost no evidence of cereal working in the houses and other contexts discussed. Wood is the most common vegetal material that was processed (Figure 10: a-b) both in a dry and soaked condition. For six tools in total, it was possible to better determine which kind of plant was worked. Traces of tubers are present in sample 4 (Figure 5: 6 and Figure 10: c) and 20 (Figure 5: 7 and Figure 10: d). A flake (sample 11, Figure 5: 8) from house 36 was used for herbaceous plant cutting, with the presence of powdery elements and abraded areas indicating that this activity was done near the ground (Figure 10: e). A blade (sample 63, Figure 5: 1) from under house 26 at Lepenski Vir and a blade (sample 101, Figure 6: 9) from trench 5 at Padina have traces connected to siliceous plant working (Figure 10: g-h). Another blade (sample 120, Figure 6: 1), from Padina (trench 6) was used near the ground for the processing of wild plants (Figure 10: i). A flake (sample 2, Figure 5: 9), found on the floor of house 36 is considered to have been used in fibre production (Figure 10: j), and so far, it is the only tool from both sites that was used in this specific process.

Macro scars are defined with the snap, step, feather and half-moon shaped scars in smaller dimensions and medium edge rounding. The majority (63\%) of tools that processed the vegetal materials were used in cutting motion, observed from the oblique bidirectional orientation of the traces.

The domed topography with flat high parts, sometimes pitted is very common for the polish that is associated with vegetal material. Linkage is from half-tight, tight to compact with a smooth texture. These are the main components that characterized polish from Lepenski Vir and Padina that is associated with vegetal-based materials.

\subsubsection{Mineral resource}

Mineral resources are the least present material that was identified. In 99\% of the sample, the working of mineral resources was associated with stone working, more precisely soft stone working.

The macro traces are small step, snap and feather scars. The micro traces are represented by usually rough texture, domed, granular and sometimes flat topography. On sample 102 (Figure 6: 10) traces limited to the processing of mineral material are visible, small macro scars and granular topography of the polish (Figure 11: a-b). Another example is a very specific flake from house 36 (Figure 5: 10) at Lepenski Vir. The activity that was done does not have a final interpretation (Figure 11: c-d), but we can conclude in general that it was a hard and dry material, mineral-based. 

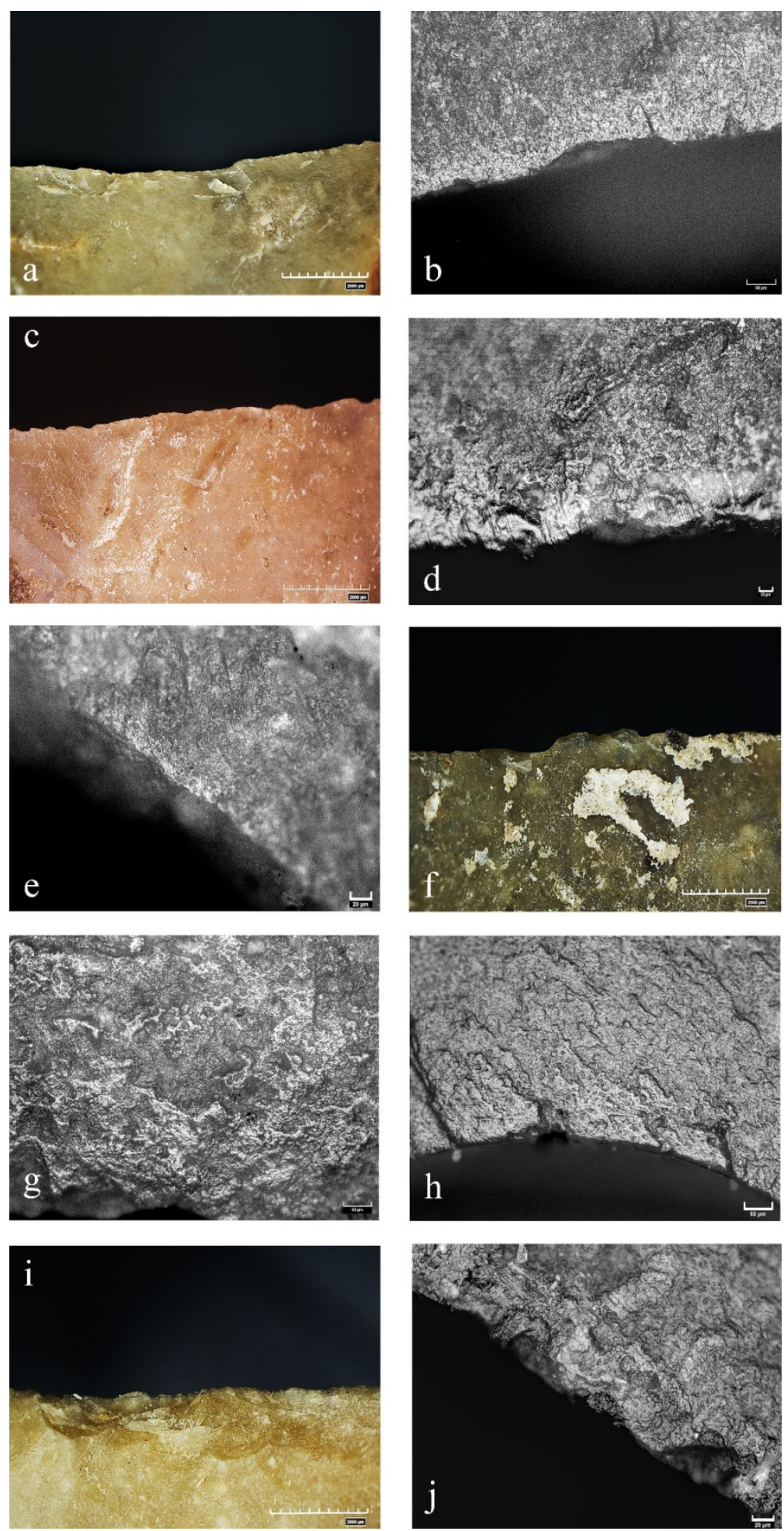

Figure 10. Vegetable-based materials a) woodworking, macro, sample 80, Padina, digital microscope, scale bar equal to $2000 \mu \mathrm{m}$, b) superposition of woodworking and animal material, micro, sample 80, metallographic microscope, scale bar equal to $50 \mu \mathrm{m}$, c) tuber working, macro, sample 4, Lepenski Vir, digital microscope, scale bar equal to $2000 \mu \mathrm{m}$, d) tuber working, micro, sample 20, Lepenski Vir, metallographic microscope, scale bar equal to $20 \mu \mathrm{m}$, e) herbaceous plant, micro, sample 11, Lepenski Vir, metallographic microscope, scale bar equal to $20 \mu \mathrm{m}, \mathrm{f}$ ) macro traces, the plant that is herbaceous towards silicious, sample 100, Padina, digital microscope, scale bar equal to $2000 \mu \mathrm{m}$, g) micro polish from silicious plants, sample 63, Lepenski Vir, metallographic microscope, scale bar equal to $50 \mu \mathrm{m}$, h) micro polish from silicious plants, sample 101, Padina, metallographic microscope, scale bar equal to $50 \mu \mathrm{m}$, i) wild plants, macro traces, sample 120, Padina, digital microscope, scale bar equal to $2000 \mu \mathrm{m}$, j) fibre production, sample 2, Lepenski Vir, metallographic microscope, scale bar equal to $20 \mu \mathrm{m}$. 

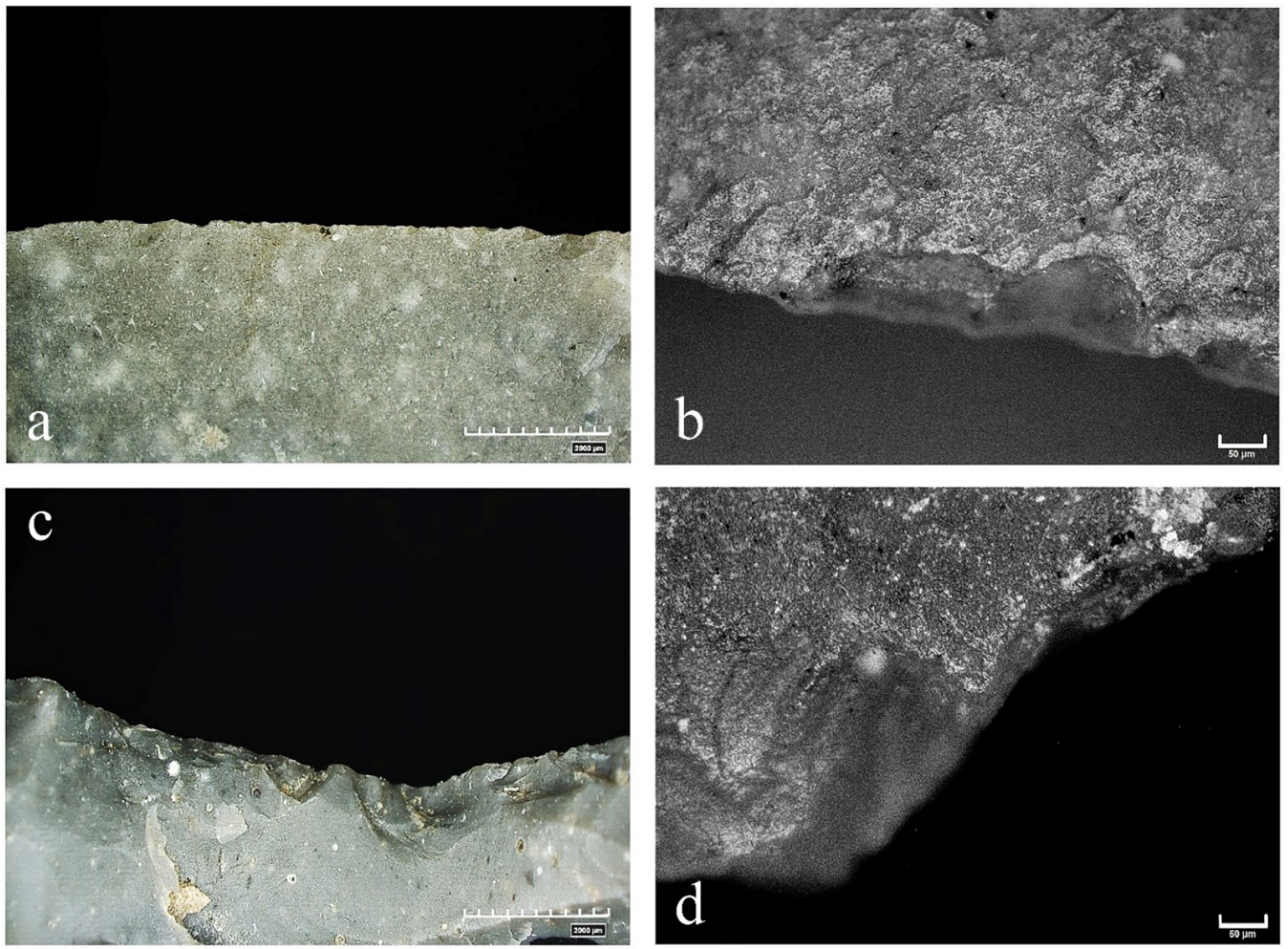

Figure 11. Mineral materials a) soft abrasive mineral material, macro, sample 102, Padina, digital microscope, scale bar equal to $2000 \mu \mathrm{m}$, b) soft abrasive mineral material, micro, sample 102, metallographic microscope, scale bar equal to $50 \mu \mathrm{m}, \mathrm{c})$ hard and dry material, mineral stone or maybe teeth work, macro, sample 25, Lepenski Vir, digital microscope, scale bar equal to $2000 \mu \mathrm{m}$, d) hard and dry material, mineral stone or maybe teeth work, micro, sample 25, metallographic microscope, scale bar equal to $50 \mu \mathrm{m}$.

\subsection{Results of FTIR analysis}

The FTIR analyses were performed to reveal the presence or absence of any micro residues. It is important to highlight that the spectroscopic analyses are additional to the usewear analysis and they are employed in this specific case to support the functional data.

In all spectra (Table 1), a very intense absorption band is observed at $1157 \mathrm{~cm}^{-1}$ and two medium intensity bands at 798 and $469 \mathrm{~cm}^{-1}$ respectively attributed to Si-O stretching and O$\mathrm{Si}-\mathrm{O}$ and, or O-Si-Al bending modes since cryptocrystalline silica is the principal constituent of the analysed items (Madejová 2003; Vaculíková \& Plevová 2005).

Table 1. Results of FTIR analysis

\begin{tabular}{lll}
\hline Sample number & Vibrational modes observed $(\mathbf{c m}-\mathbf{1})$ & Proposed assignment \\
\hline Sample 35 & $2916,2847,1576,1536, \sim 913$ & Adipocere, bone \\
Sample 31 & $2916,2847,1576,1536, \sim 1460, \sim 913,877$ & Adipocere, CaCO3, bone \\
Sample 39 & $2916,2847,1576,1536, \sim 1460, \sim 913,877$ & Adipocere, CaCO3, bone \\
Sample 75 & $1576,1536, \sim 1460$ & Adipocere, CaCO3 \\
Sample 11 & $1554,1518,877$ & CaCO3 \\
Sample 29 & $1554,1518,877$ & CaCO3 \\
Sample 120 & $3750,2916,2847,1705,1650,1550$ & Lignin, cellulose \\
Sample 4 & $3750,2916,2847,1705,1650,1550,1460$ & Lignin, cellulose, CaCO3 \\
\hline
\end{tabular}


All peaks show an up-down reversal due to the restrahlen effect (Madejová \& Komadel 2001).

Doublets at 1575, 1536 and 2915, $2848 \mathrm{~cm}^{-1}$ are present at least at one point of many samples. They are confidently attributed to the $\mathrm{C}-\mathrm{O}$ and $\mathrm{C}-\mathrm{H}$ stretching mode of fatty acids salts (palmitate and or stearate), (Gönen et al. 2010; Hénichart et al. 1982).

These compounds are present both in vegetal (Raíces et al. 2003; Woodfield et al. 2017) and soft animal tissues. In the latter case, their presence is due to the transformation of animal body fat into a greasy lipid mixture called adipocere (Stuart et al. 2000).

Micro residues of fatty acids and their salts survive very long on archaeological artefacts since they are not soluble in water and have a waxy consistency which allows their penetration in the micro holes of the microcrystalline flint.

The mentioned doublet is present in the spectra of samples 35 (Figure 5; 15 and Figure 12: a), 31 (Figure 5: 14 and Figure 12: b) and 39 (Figure 5: 16 and Figure 12: c). In addition, a shoulder is observed on the low-frequency side of the most intense band of flint (approximately at $913 \mathrm{~cm}^{-1}$ ). This feature can be attributed to calcium phosphate the mineral constituent of bones (Sauer \& Wuthier 1988) or to the aluminium silicate present in clay (kaolinite) (Prost et al. 1989) A sure attribution can be obtained only by comparing spectroscopic suggestions to use wear or elemental analysis results.

In the spectra of many samples, a broadband centred approximately at $1460 \mathrm{~cm}^{-1}$ is observed and assigned to the carbon-oxygen stretching mode of calcium carbonate. Its intensity is highly variable depending on the amount of residue present. In the case of medium or high intensity, an additional feature is also detected at $877 \mathrm{~cm}^{-1}$ belonging to the oxygencalcium-oxygen bending mode of the compound (Bosch Reig et al. 2002). It is worth observing that the spectrum of the cortex of sample 75 (Figure 5: 18 and Figure 12: d) shows an intense amount of calcium carbonate hiding also the intense spectra of flint. Bands are observed also in the $1700-2600 \mathrm{~cm}^{-1}$ frequency range attributed to the overtones modes of the compound.

In the infrared spectrum of sample 11 (Figure 5: 8 and Figure 12: e) and 29 (Figure 5: 3 and Figure 12: f) bands are observed at 1554, 1518 and $877 \mathrm{~cm}^{-1}$ suggesting the existence of residues of sparitic limestone, a carbonate sedimentary rock (Poduska et al. 2012). The broadness and the intensity of the feature lying around $1500 \mathrm{~cm}^{-1}$ prevent the detection of micro residues of different nature.

The spectroscopic analysis of some samples such as sample 120 (Figure 6: 11 and Figure 12: g) and sample 4 (Figure 5: 6 and Figure 12: h) showed the presence of weak broad absorption bands observed in the $1750-1500 \mathrm{~cm}^{-1}$ interval $\left(1705, \sim 1650\right.$ and $\left.\sim 1550 \mathrm{~cm}^{-1}\right)$ suggesting the existence of lignin and, or cellulose residues (Boeriu et al. 2004; Schwanninger et al. 2004) whose most intense active bands, unfortunately, lie under the Si-O stretching mode of flint. The proposed attribution is however supported by use-wear results. 

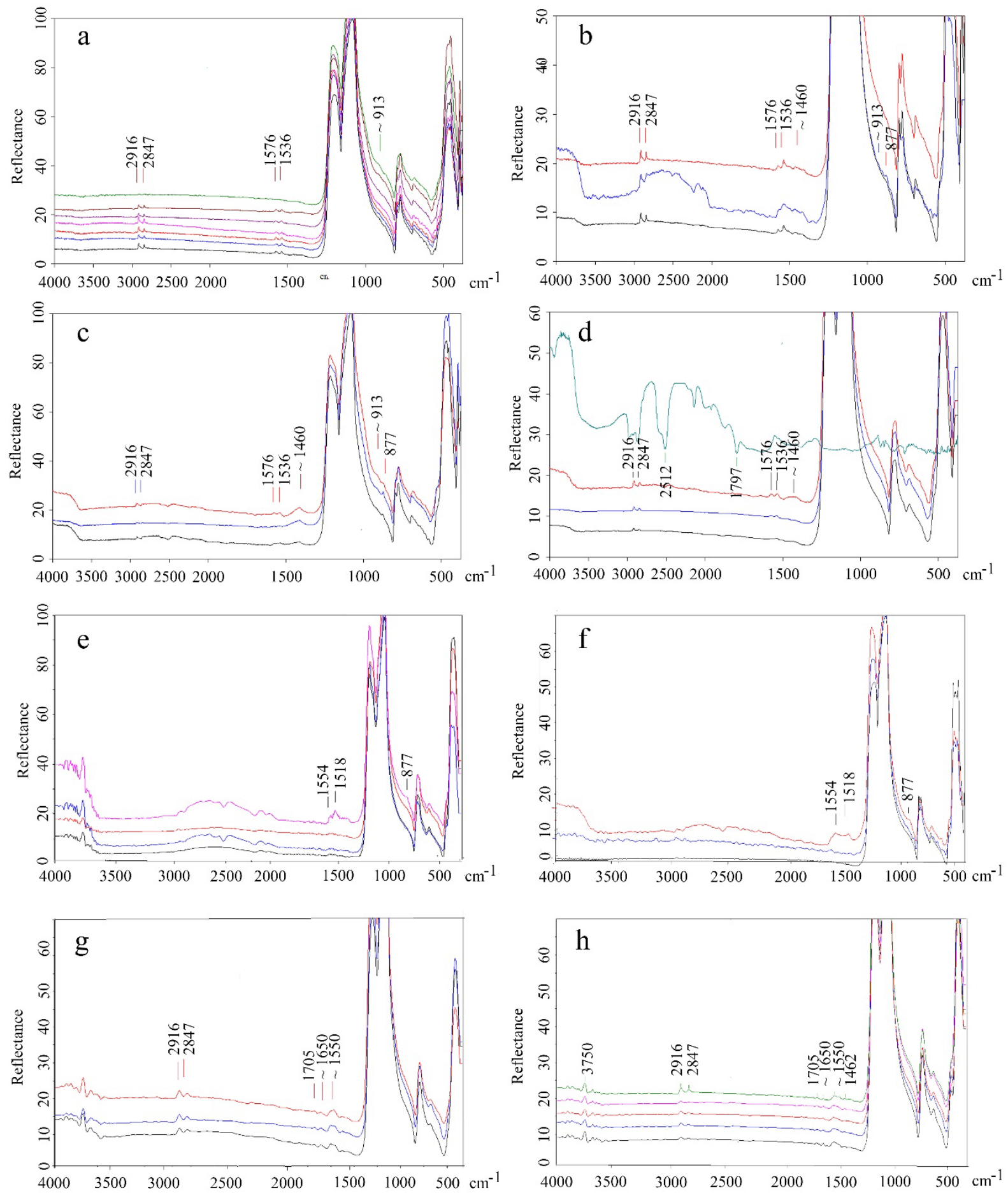

Figure 12. MicroFTIR spectrums of a) sample 35, Lepenski Vir b) sample 31, Lepenski Vir c) sample 39, Lepenski Vir d) sample 75, Lepenski Vir e) sample 11, Lepenski Vir f) sample 29, Lepenski Vir g) sample 120, Padina h) sample 4, Lepenski Vir

\section{Discussion and conclusions}

The importance of the chosen contexts lies in the absolute dates that are connected to these areas, hence the transitional period in Iron Gates. The sample as previously stated is altered, but in general, preserved in good condition, and provides many interesting and firm proofs of various activities in the region.

In addition to the differentiation between materials and activities, many tools were used for specific tasks, like working of small pieces of hide. This was concluded based on the 
polish distribution and dimensions of the used tools. The environment of some of the processes is also known thanks to the use-wear traces. In sample 7 (Figure 5: 11), 11 (Figure 5: 8, Figure 10: e and Figure 12: e), sample 14 (Figure 5: 12), 41 (Figure 5: 17), and sample 76 (Figure 5: 19) we can note the abrasion that is connected to the dusty zone where the activity was done, as in these cases on or near the ground and in open-air spaces in general. Use-wear interpretations are supported by FTIR results that showed traces of calcium carbonate. These residues can be proof of the surroundings where the materials were worked in the past. Moreover, dust or sand particles were mixed with contact materials, as in the case of hide, or other matters that were processed on the ground where they could easily become contaminated. It can also be explained as a taphonomic deposit, but this theory is excluded in the case of the studied material, since it was cleaned several times, including a laboratory washing procedure used for functional analysis. Many tools, mostly from Sector I at Padina sample 78 (Figure 6: 2 and Figure 13: a), 79 (Figure 6: 3 and Figure 9: f), and 81 (Figure 6: 5, Figure 9: a and Figure 13: b) showed traces of use on both working edges together with the superposition of the prehension patches. This practice testifies to the extensive use of the tools. Even though the raw materials and the tools produced were quantitatively large, the need for the utilization of all the possible edges is developed, which can be considered as the main characteristic of the recycling behaviour of these communities.
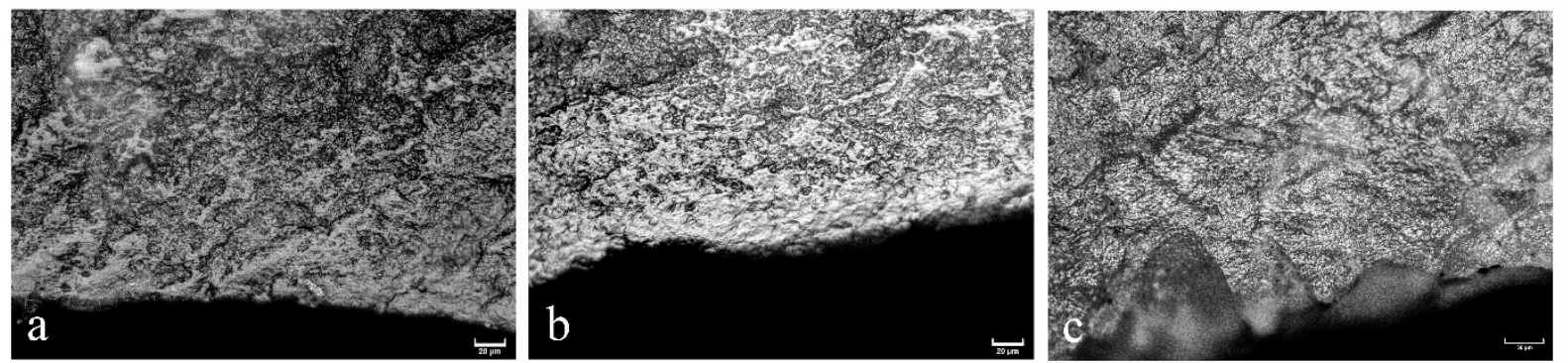

Figure 13. Traces of hafting and wrapping, metallographic microscope a) sample 78, hafting traces, scale bar equal to $20 \mu \mathrm{m}$, b) sample 81, hafting traces, scale bar equal to $20 \mu \mathrm{m}, \mathrm{c}$ ) sample 77 , wrapping and use, superposition, scale bar equal to $50 \mu \mathrm{m}$.

The nature of residues detected on archaeological tools can be ascertained only by comparing the spectroscopic results to the suggestions of use-wear analysis and creating a more complete picture of both activity and used material. In the case of all the twenty-five (25) studied samples there was a complete match between the residues found and the activity observed by functional analysis.

The following conclusions were reached regarding the samples analysed from houses at Lepenski Vir.

The samples from under the floor of house 26, connected to the period of use of trapezoidal buildings (6212-6025 cal BCE) have a unique situation regarding the activity conducted. In this phase of the occupation of this area, cutting was performed by $65 \%$ of the tools recovered from this context. Three tools were used in the processing of vegetable materials, one for siliceous plants, and one for wood in general and one for fresh wood. Animal materials processed with these tools were hide and meat. This altogether testifies about the diverse processes that took place, not limiting the use of the space to only one activity. The processes could be classified as daily activities during the transitional period at Lepenski Vir. This is a piece of very important information since the position of house 26 and house 26' is labelled beside the sanctuary as marked on the bag with animal remains (Dimitrijević 2008:7), giving a certain level of importance to this building. 
Results gathered from house 36 are probably the most suggestive data about the community of the Lepenski Vir during the transition from Late Mesolithic to Early Neolithic. This house, together with house 35 and 32 was considered as one of the houses where knapping took place (Mitrović 2018). From the use-wear results, it can be said that house 36 was very specialized in the processing of skin products and that the motion of cutting is strongly represented (53\%). Tools that were used for refinement of the hide, the treatment of small hide objects, as belts and tiny garments, are found together with hide in various stages of preparation from fresh to semi-fresh to dry and traces of butchering. Also, activities on vegetable material are noted, including tubers, herbaceous plants, wood and one tool used for fibre production, which testifies to the variety of activities that took place in the building. On the floor of house 36, a semifinished mallet resembling an axe, weight, and an anvil (Antonović 2006:65, 68, 78) together with remains of wild boar and fish were found (Dimitrijević 2008: 5).

House 32, dated to 6061-5902 cal BCE, has an equal number of the non-diagnostic pieces (26\%) and tools involved in activities with animal materials (26\%), such as fresh hide, bone, and butchering. Around 5\% of the total tools were analysed based only on macro traces, so the exact worked material cannot be determined, but so far, there are no indications of vegetable processing in this area. Based on technological analysis of the artefacts produced on grey flint it is noticeable that blanks of this raw material were brought inside the house and, thus, it was presumed that they were left for further shaping (Mitrovic 2018). Still, these tools were used, even considered unfinished which is indicative of human behaviour and their economic choices. Together with these artefacts, one pebble without any traces of trimming was also found on the house floor (Antonović 2006:92) and remains of a dog, red deer and fish.

The two artefacts from a midden are associated with the Early Neolithic period since they were found together with Starčevo pottery and show traces exclusively connected to butchering and fresh hide processing. The traces also show signs of activity done in the open based on the abrasion created by the dusty environment. This indicates the possibility of discard of these tools after use and placing them in a midden together with fragments of ceramics.

The results of tools used on the Padina site, unfortunately, cannot be discussed in detail since not all the artefacts are directly associated with houses in all cases.

However, the position of some of the artefacts is clear given the dating of block $1 \mathrm{~b}$ from Sector I (6650-6460 cal BCE). One of the blades found under hearth number 1614 was used specifically for butchering, and the traces show the superposition of a series of butchering and skinning (sample 77, Figure 6: 1 and Figure 9: g). What is interesting are the traces of wrapping (Figure 13: c). This method of adapting the tool for handling was not detected so far in any other area or site in the region, but it is noted also on the other larger blade (sample 81, Figure 6: 5, Figure 9: a and Figure: 13: b) produced by pressure technique from the same context and used for hide processing. The specified handling of these two blades raises the question of their role in particular tasks and implies the nature of the activity was perhaps uncommon.

Regarding Sector III, artefacts from trench 5 and 6 for the most part can be discussed based on their use, since their exact location inside the block is not identified (e.g., trench 5 has two blocks, and block 1 has three houses 16, 17 and 18), although for some tools the location is specified as a hearth in the central part of the block, or under or on the stone construction. It should be noted that most of the tools were made on Balkan flint and it is typo-technologically categorized as an Early Neolithic assemblage which corresponds with the absolute dates, same as in trench 6 . At least $40 \%$ of the artefacts from trench 5 and 6 were 
used in the processing of the animal materials, and only three tools relate to use on vegetable materials.

Trench 3 has very specific results. This context has no absolute dates available, but it is mentioned that a couple of the lithic tools have been found in the block with atypical ceramics under the construction from the Iron Age period. Four out of five tools found in this trench, however, indicate work on animal material. Three tools are connected to use on hard animal material (bone and antler), sample 113 (Figure 8: c-d), 114, (Figure 8: a-b), and 115 (Figure 8: e-f). FTIR analysis confirmed the presence of calcium on sample 115 and fatty acids salts which correspond to the use of hide as the use-wear traces show. These results together with other tools that were used for processing of hard animal material on both sites are important to highlight since they point out the evident craft activities of creation and maintenance of tools made on bone and antler.

In general, in Sector III only two tools have traces from different activities, one has a superposition of the two uses, a bone and another unidentified material (sample 114) and the other blade (sample 117) has traces of use on hide on the left edge and right edge has been used for processing of hard animal material. This is different from the situation at Lepenski Vir where the utilization of both edges, the morphological shape of the tool and superposition of the traces is not rare.

The wide spectrum of activities found on both sites suggests developed processes that took part in the region of the Iron Gates. The prevalence of the use of knapped stone tools for hide and animal-based materials at Lepenski Vir suggests a possibility of the developed processing of leather goods in the community. It is often pointed out that the economy of the Iron Gates region was largely based on fishing in the Late Mesolithic. However, traces connected specifically to fish working on lithic tools represent a very important subject, having in mind that is not always possible to recognize them, therefore their definition together with a more accurate experimental trial will be treated in the separate paper (Petrović et al. 2020).

In the Transitional to Early Neolithic period, things change when the consumption of both terrestrial and aquatic resources is present (Dimitrijević 2000; 2008; Dimitrijević et al. 2016; Živaljević 2017). The use-wear results discussed in this paper complement the archaeozoological evidence and suggest that other than fish, other animals were also hunted. Domesticated species appear in the archaeological record a bit later in the Early and Middle Neolithic, and it is important to connect this animal material processing with the continued prevalence of wild species, as previously noted (Bökönyi 1972).

Various plants, herbaceous, siliceous and wild, were worked as well on both sites, but the samples from these houses and contexts do not show any tools that worked cereals. The question arises how cereals were harvested and collected, by hand or some other tools, having in mind that around the $6^{\text {th }}$ millennium BCE domesticated species were already consumed by the inhabitants of the Lepenski Vir (Cristiani et al. 2016).

This carefully thought out approach of meat and hide processing, with a series of operational stages of work to the smallest detail is reviving interest in population nutrition research at Iron Gates. These subtleties remind us that every settlement and community, not only Lepenski Vir and Padina, must be approached with great caution and without preconceived views on radical changes in diet and basic activities in the use of by-products that would be implied in such a large population and social changes such as the period of transition from the Mesolithic to the Neolithic. 


\section{Acknowledgements}

We are grateful to colleague Đorđe Radonjić (University of Belgrade) for his generous help and technical support regarding the illustrations. We are thankful to MAECI - Ministry of Foreign Affairs and International Cooperation (Ministero degli Affari Esteri e della Coperazione Internazionale) for the financial support of this research.

The results reported in this paper are part of the wider study addressed in the $\mathrm{PhD}$ thesis entitled Mesolithic-Neolithic transition in Iron Gates (Serbia): human activities from usewear perspective by Anđa Petrović, Sapienza University of Rome and the University of Belgrade, within the project Cultural changes and population movement in early prehistory of the Central Balkans (project director professor D. Mihailović, University of Belgrade).

\section{Data accessibility statement}

The authors confirm that the data supporting the findings of this study are available within the article and its supplementary files.

\section{List of supplementary files}

Supplementary file 1

"PETROVIĆ et al.- supplementary file 1 - PETROVIĆ_et al-Table 1.xls"

Complete list of the analysed samples from Lepenski Vir and Padina together with the main use-wear results.

Supplementary file 2

"PETROVIĆ et al.-supplementary file 2 - PETROVIĆ_et al-Glossary.docx"

Glossary of microwear therms used in the study

\section{References}

Antonović, D. 2006, Stone tools from Lepenski Vir. Cahiers des Portes de Fer, Monographies Vol. 5, Institute of Archaeology, Belgrade, 155 p.

Binder, D. \& Gassin, B. 1988, Le débitage laminaire chasséen apres chauffe: technologie et traces d'utilisation. In: Industries lithiques. Tracéologie et Technologie (Beyries, S., Ed.), BAR International Series Vol. 411(1), British Archaeological Reports, Oxford:93125. (in French) ("The Chassean laminar production after heating treatment: Technology and use-wear traces”)

Boeriu, C., Bravo, D., Gosselink, R. \& van Dam, J. 2004, Characterisation of structuredependent functional properties of lignin with infrared spectroscopy. Industrial Crops and Products, 20: 205-218. doi:10.1016/j.indcrop.2004.04.022

Bogosavljević-Petrović, V. \& Starović, A. 2013, Balkanski kremen iz zbirke za stariji neolit Narodnog muzeja u Beogradu. Zbornik Narodnog muzeja, 21(1): 77-108. (in Serbian) ("Balkan flint from the Early Neolithic collection at the National Museum in Belgrade")

Bökönyi, S. 1972, The vertebrate fauna. In: Europe’s first monumental sculpture: New discoveries at Lepenski Vir (Srejović, D., Ed.), Thames and Hudson, London: p. 186189. 
Bonsall, C., Cook, G.T., Hedges, R.E.M., Higham, T.F.G., Pickard, C. \& Radovanović, I. 2004, Radiocarbon and Stable Isotope Evidence of Dietary Change from the Mesolithic to the Middle Ages in the Iron Gates: New Results from Lepenski Vir. Radiocarbon, 46(1): 293-300. doi:10.1017/S0033822200039606

Bonsall, C., Radovanović, I., Roksandić, M., Cook, G.T., Higham, T.F.G. \& Pickard, C. 2008, Dating burials and architecture at Lepenski Vir. In: The Iron Gates in Prehistory: New Perspectives (Bonsall, C., Boroneanţ, V. \& Radovanović, I., Eds.), Archaeopress, Oxford: p. 175-204.

Borić, D, 2011, Adaptations and transformations of the Danube Gorges foragers (c. 13.0005500 BC): An overview. In: Beginnings - New Research in the Appearance of the Neolithic between Northwest Anatolia and the Carpathian Basin (Kraus, R., Ed.), Verlag Marie Leidorf Gmbh, Rahden: p. 157-203.

Borić, D. 2016, Posmrtni obredi na Lepenskom Viru: obrasci pogrebne prakse. Iskopavanja Dragoslava Srejovića / Deathways at Lepenski Vir: Patterns in Mortuary Practice. Excavations of Dragoslav Srejović, Serbian Archaeological Society, Belgrade, 565 p.

Borić, D. 2019, Lepenski Vir Chronology and Stratigraphy Revisited. Starinar, 69: 9-60. doi:10.2298/STA1969009B

Borić, D. \& Dimitrijević, V. 2007, Апсолутна хронологија и стратиграфија Лепенског Bupa (Apsolutna hronologija i stratigrafija Lepenskog Vira). Starinar, 57: 9-55. (in Serbian and English) (“Absolute chronology and stratigraphy of Lepenski Vir”) doi:10.2298/STA0757009B

Borić, D., Grupe, G., Peters, J. \& Mikić, Ž. 2004, Is the Mesolithic-Neolithic subsistence dichotomy real? New stable isotope evidence from the Danube Gorges. European Journal of Archaeology, 7(3): 221-248. doi:10.1177/1461957104056500

Borić, D., Higham, T., Cristiani, E., Dimitrijević, V., Nehlich, O., Griffiths, S., Alexander, C., Mihailović, B., Filipović D., Allué, E. \& Buckley, M. 2018, High-Resolution AMS Dating of Architecture, Boulder Artworks and the Transition to Farming at Lepenski Vir, Scientific Reports, 8: 14221. doi:10.1038/s41598-018-31884-7

Borić, D. \& Miracle, P. 2004, Mesolithic and Neolithic (dis)continuities in the Danube Gorges: New AMS dates from Padina and Hajdučka Vodenica (Serbia). Oxford Journal of Archaeology, 23(4): 341-371. doi:10.1111/j.1468-0092.2004.00215.x

Borić, D. \& Stefanović, S. 2004, Birth and death: Infant burials from Vlasac and Lepenski Vir. Antiquity, 78: 526-546. doi:10.1017/S0003598X00113201

Bosch Reig, F., Gimeno Adelantado, J.V. \& Moya Moreno, M.C.M. 2002, FTIR quantitative analysis of calcium carbonate (calcite) and silica (quartz) mixtures using the constant ratio method. Application to geological samples. Talanta, 58: 811-921. doi:10.1016/S0039-9140(02)00372-7

Clemente-Conte, I. 1997, Thermal alterations of flint implements and the conservation of microwear polish: Preliminary experimental observations. In: Siliceous Rocks and cultures, (Ramos Millán, A. \& Bustillo, M.A. Eds.), Universidad de Granada, Granada: p. 525-535.

Cristiani, E., Radini, A., Edinborough, M. \& Borić, D. 2016, Dental calculus reveals Mesolithic foragers in the Balkans consumed domesticated plant foods. Proceeding of National Academy of Sciences, 113(37): 10298-10303. doi:10.1073/pnas.1603477113 
Dimitrijević, V. 2000, The Lepenski Vir fauna: bones in houses and between houses. Documenta Praehistorica, 27: 101-117.

URL: http://www.dlib.si/details/URN:NBN:SI:DOC-2H9P3LYG

Dimitrijević, V. 2008, Lepenski Vir animal bones: What was left in the houses? In: The Iron Gates in prehistory New perspectives (Bonsall, C., Boroneanţ, V. \& Radovanović, I., Eds.), BAR International Series Vol. 1893, Archaeopress, Oxford: p. 117-130.

Dimitrijević, V., Živaljević, I. \& Stefanović, S. 2016, Becoming sedentary? The seasonality of food resource exploitation in the Mesolithic-Neolithic Danube Gorges. Documenta Praehistorica, 43: 103-122. doi:10.4312/dp.43.4

Domański, M. \& Webb, J. 1992, Effect of heat treatment on siliceous rocks used in prehistoric lithic technology. Journal of Archaeological Science, 19(6):601-614. doi:10.1016/0305-4403(92)90031-W

Filipović, D., Allué, E.A. \& Borić, D. 2010, Integrated carpological and anthracological analysis of plant record from the Mesolithic site of Vlasac, Serbia. Journal of Serbian Archaeological Society, 26: 145-161.

Gönen, M., Öztürk, S., Balköse, D., Okur, S. \& Ülkü, S. 2010, Preparation and Characterization of Calcium Stearate Powders and Films Prepared by Precipitation and Langmuir-Blodgett Techniques. Industrial \& Engineering Chemistry Research, 49: 1732-1736. doi:10.1021/ie901437d

Gurova, M. 2008, Toward an understanding of Early Neolithic populations: a flint perspective from Bulgaria. Documenta Praehistorica, 35: 111-129. doi:10.4312/dp.35.8

Gurova, M., Andreeva, P., Nikolov, A., Barbov, B. \& Kostadinova-Avramova, M. 2020, Heat alterations of flint artefacts: Archaeological evidence, experiments and analyses.

Bulgarian e-Journal of Archaeology, 10(1): 111-141.

URL: https://be-ja.org/index.php/journal/article/view/be-ja-10-1-2020-111-141

Gurova, M., Andreeva, P., Stefanova, E., Stefanov, Y., Kočić, M. \& Borić, D. 2016, Flint raw material transfers in the prehistoric Lower Danube Basin: An integrated analytical approach. Journal of Archaeological Science Reports, 5: 422-441. doi:10.1016/j.jasrep.2015.12.014

Halbrucker, É., Fiers, G., Vandendriessche, H., De Kock, T., Cnudde, V. \& Crombé, P. 2021, Burning flint: An experimental approach to study the effect of fire on flint tools. Journal of Archaeological Science: Reports, 36: 02854. doi:10.1016/j.jasrep.2021.102854

Hénichart, J.P., Bernier, J.L., Roman, M. \& Roussel, P. 1982, Identification of calcium palmitate in gallstones by infra-red spectroscopy. Clinica Chimica Acta, 118: 279-287. doi:10.1016/0009-8981(82)90014-6

Jovanović, B. 1987, Die Architektur und Keramik die Siedlung Padina B im eiserner Tor, Jugoslawien. Germania, 65: 1-16. (in German) ("The Architecture and Pottery from settlement Padina B in Iron Gates”)

Jovanović, J., de Becdelièvre, C., Stefanović, S., Živaljević, I., Dimitrijević, V. \& Goude, G. 2019, Last hunters-first farmers: New insight into subsistence strategies in the Central Balkans through multi-isotopic analysis. Journal of Archaeological and Anthropological Science, 11: 3279-3298. doi:10.1007/s12520-018-0744-1 
Kozłowski, J. \& Kozłowski, S. 1984, Chipped stone industries from Lepenski Vir. Preistoria Alpina, 19: 259-293.

URL: https://www2.muse.it/pubblicazioni/7/19/KozlowskiJK,KoslowskiSK1984_PA19 _Chipped\%20Stone\%20Industries\%20from\%20Lepenski\%20Vir.\%20Yugoslavia_IM M\&OCR.pdf

Madejová, J. 2003, FTIR techniques in clay mineral studies. Vibrational Spectroscopy, 31:110. doi:10.1016/S0924-2031(02)00065-6

Madejová, J. \& Komadel, P. 2001, Baseline studies of the clay minerals society source clays: Infrared methods. Clays and Clay Minerals, 49(5): 410-432. doi:10.1346/CCMN.2001.0490508

Mihailović, D. 2004, Chipped stone industry from horizons A and B at the site of Padina in the Iron Gates. In: Late Foragers and Early Farmers of the Lepenski Vir - Schela Cladovei Culture in the Iron Gates Gorges. A metamorphosis of Technologies or Acculturations (Acts of the XIVth UISPP Congress, Liege 2001), BAR International Series Vol. 1302, Archaeopress, Oxford: p. 61-68.

Mitrović, M. 2018, Industrije okresanog kamena u mezolitu Đerdpa. Ph.D thesis at the Department of Archaeology, University of Belgrade, Belgrade, 268 p. (in Serbian) ("Knapped stone industries in the Iron Gates Mesolithic")

Olausson, D. 1983, Experiments to investigate the effects of heat treatment on usewear on flint tools. Proceedings of the Prehistoric Society, 49: 1-13.

Patterson, L. 1995, Thermal damage of chert. Lithic Technology, 20(1): 72-80. URL: https://www.jstor.org/stable/23273161

Petrović, A. \& Moscone, D. 2019, Flint, Quartzite and Fire: Alteration of tool surface on micro-scale. In: EAC11 Experimental Archaeology Conference 2-4 May 2019, Trento, Italy, Program: Papers, Posters, Excursions (Grimaldi, S., Paardekooper, R., Costa, A. \& Zielińska, M., Eds.), EXARC, University of Trento, Trento: p. 49.

Petrović, A., Lemorini, C., Nunziante Cesaro, S. \& Živaljević, I. 2020, To fish or not to fish? Fish processing at Iron Gates: An experimental approach. In: Meso'2020 -Tenth International Conference on the Mesolithic in Europe 7-11 Sep 2020 Toulouse France, book of abstracts (Perrin, T., Marquebielle, B., Philibert, S. \& Valdeyron, N., Eds.), University Toulouse, Toulouse: p. 310.

Purdy, B. \& Brooks, H. 1971, Thermal Alteration of Silica Minerals: An Archeological Approach. Science, 173(3994): 322-325. doi:10.1126/science.173.3994.322

Poduska, K.M., Regev, L., Berna, F., Mintz, E., Milevski, I., Khalaily, H., Weiner, S. \& Boaretto, E. 2012, Plaster characterization at the PPNB Site of Yiftahel (Israel) including the use of 14C: Implications for plaster production, preservation, and dating. Radiocarbon, 54(3-4): 887-896. doi:10.1017/S0033822200047536

Prost, A., Dameme, E.H., Driard, J. \& Leydecker, J.P. 1989, Infrared study of structural OH in Kaolinite, Dickite, Nacrite, and poorly crystalline Kaolinite at 5 to 600K. Clays and Clay Minerals, 37(5): 464-468. doi:10.1346/CCMN.1989.0370511

Radović, M. \& Stefanović, S. 2015, An osteobiography from Lepenski Vir: Paramasticatory use of teeth and musculoskeletal stress of a woman dated to the Early Neolithic. In: Muge 150th The 150th Anniversary of the Discovery of Mesolithic Shellmiddens (Bicho, N., Detry, C., Price, D. Eds.), Cambridge Scholars Publishing, Cambridge: p. 267-278. 
Radovanović, I. 1981, Ranoholocenska kremena industrija sa lokaliteta Padina u Đerdapu. Institute of Archaeology, Belgrade, 139 p. (in Serbian) ("Early Holocene Flint Industry from the Site of Padina in the Iron Gates”)

Radovanović, I., 1992, Mezolit Đerdapa. Ph.D thesis at the Department of Archaeology, University of Belgrade, Belgrade, 454 p. (in Serbian) ("The Iron Gates Mesolithic”)

Radovanović, I. 1996, The Iron Gates Mesolithic. International Monographs in Prehistory, Ann Arbor, Michigan, 382 p.

Raíces, M., Rubén Gargantini, P., Chinchilla, D., Crespi, M., Téllez-Iñón, M.T. \& Ulloa, R.M. 2003, Regulation of CDPK isoforms during tuber development. Plant Molecular Biology, 52: 1011-1024. doi:10.1023/A:1025478315648

Roksandic, M. 2000, Between foragers and farmers in the Iron Gates Gorge: Physical antropology perspective. Documenta Praehistorica, 27: 1-100.

URL: http://www.dlib.si/details/URN:NBN:SI:DOC-N988W3AG

Roksandic, M. 2012, Mobile and terrestrial but firmly rooted on the river banks: Biological anthropology of Lepenski Vir and the Iron Gates Gorge Mesolithic. Advances in Anthropology, 2(3): 117-124. doi:10.4236/aa.2012.23014

Rutkoski, A.R., Miller, G.L., Maguire, L., Eren, M.I., Bebber, M.R. 2019, The effect of heat on lithic microwear traces: An experimental assessment. Lithic Technolology: 1-10. doi:10.1080/01977261.2019.1690617

Sauer, G. \& Wuthier, R. 1988, Fourier Transform Infrared Characterization of Mineral Phases Formed during Induction of Mineralization by Collagenase-released Matrix Vesicles in vitro. The Journal of Biological Chemistry, 263(27): 13718-13724. doi:10.1016/S00219258(18)68300-0

Schmidt, P., Masse, S., Laurent, G., Slodczyk, A., le Bourhis, E., Perrenoud, C., Livage, J. \& Fröhlich, F. 2012, Crystallographic and structural transformations of sedimentary chalcedony in flint upon heat treatment. Journal of Archaeological Science, 39(1): 135144. doi:10.1016/j.jas.2011.09.012

Schwanninger, M., Rodrigues, J.C., Pereira, H. \& Hinterstoisser, B. 2004, Effects of shorttime vibratory ball milling on the shape of FT-IR spectra of wood and cellulose. Vibration Spectroscopy, 36: 23-40. doi:10.1016/j.vibspec.2004.02.003

Srejović, D. 1969, Lepenski Vir: Nova praistorijska kultura u Podunavlju. Serbian Literary Cooperative, Belgrade, 328 p. (in Serbian) ("Lepenski Vir: New prehistoric culture in Podunavlje”)

Stuart, B.H., Forbes, S., Dent, B.B. \& Hodgson, G. 2000, Studies of adipocere using diffuse reflectance infrared spectroscopy. Vibrational Spectroscopy, 24: 233-242. doi:10.1016/S0924-2031(00)00097-7

Šarić, J. 2014. Artefakti od okresanog kamena u starijem I srednjem neolitu na tlu Srbije. Institute of Archaeology, Belgrade, 299 p. (in Serbian) ("Early and Middle knapped stone artefacts from Serbia”)

Vaculíková, L. \& Plevová, E. 2005, Identification of clay minerals and micas in sedimentary rocks. Acta Geodynamica et Geomaterialia, 2: 167-175.

URL: https://www.irsm.cas.cz/materialy/acta_content/2005_02/20_Vaculikova.pdf 
Woodfield, H.K., Sturtevant, D., Borisjuk, L., Munz, E., Guschina, I.A., Chapman, K. \& Harwood, J.L. 2017, Spatial and Temporal Mapping of Key Lipid Species in Brassica napus Seeds. Plant Physiology, 173: 1998-2009. doi:10.1104/pp.16.01705

Živaljević, I., Popović, D., Snoj, A. \& Marić, S. 2017, Ancient DNA analysis of cyprinid remains from the Mesolithic-Neolithic Danube Gorges reveals an extirpated fish species Rutilus frisii (Nordmann, 1840). Journal of Archaeological Science, 79:1-9.

doi:10.1016/j.jas.2017.01.002 